OPEN ACCESS

Edited by: Lars Bejder,

University of Hawai'i at Mānoa, United States

Reviewed by:

Luis Cardona,

University of Barcelona, Spain

Neil Randell Loneragan,

Murdoch University, Australia

*Correspondence: Alyson H. Fleming

FlemingA@Sl.edu;

alyson.fleming@gmail.com

Specialty section:

This article was submitted to

Marine Megafauna,

a section of the journal

Frontiers in Marine Science

Received: 20 December 2017

Accepted: 04 September 2018

Published: 25 September 2018

Citation:

Fleming $A H$, Kellar NM, Allen CD and

Kurle CM (2018) The Utility

of Combining Stable Isotope and Hormone Analyses for Marine

Megafauna Research.

Front. Mar. Sci. 5:338.

doi: 10.3389/fmars.2018.00338

\section{The Utility of Combining Stable Isotope and Hormone Analyses for Marine Megafauna Research}

\author{
Alyson H. Fleming ${ }^{1,2 *}$, Nicholas M. Kellar ${ }^{3}$, Camryn D. Allen ${ }^{4}$ and Carolyn M. Kurle ${ }^{5}$ \\ ${ }^{1}$ Department of Paleobiology, National Museum of Natural History, Smithsonian Institution, Washington, DC, United States, \\ ${ }^{2}$ Department of Biology and Marine Biology, University of North Carolina at Wilmington, Wilmington, NC, United States, \\ ${ }^{3}$ Ocean Associates, Inc., Marine Mammal and Turtle Division, Southwest Fisheries Science Center, National Marine Fisheries \\ Service, National Oceanic and Atmospheric Administration, La Jolla, CA, United States, ${ }^{4}$ The Joint Institute for Marine \\ and Atmospheric Research, Protected Species Division, Pacific Islands Fisheries Science Center, National Marine Fisheries \\ Service, National Oceanic and Atmospheric Administration, Honolulu, HI, United States, ${ }^{5}$ Division of Biological Sciences, \\ Ecology, Behavior, and Evolution Section, University of California, San Diego, La Jolla, CA, United States
}

Stable isotope and hormone analyses offer insight into the health, stress, nutrition, movements, and reproduction of individuals and populations. Such information can provide early warning signs or more in-depth details on the ecological and conservation status of marine megafauna. Stable isotope and hormone analyses have seen rapid development over the last two decades, and we briefly review established protocols and particular questions emphasized in the literature for each type of analysis in isolation. Little has been published utilizing both methods concurrently for marine megafauna yet there has been considerable effort on this front in seabird and terrestrial predator research fields. Using these other taxa as examples, we offer a few of the major research areas and questions we foresee as productive for the intersection of these two methods and discuss how they can inform marine megafauna conservation and management efforts. Three major research areas have utilized a combination of these two methods: (1) nutrition and health, (2) reproduction, and (3) life history. We identify a fourth area of research, examinations of evolutionary versus ecological drivers of behavior, that could also be well served by a combined stable isotope and hormone analyses approach. Each of these broad areas of research will require methodological developments. In particular, research is needed to enable the successful temporal alignment of these two analytical techniques.

Keywords: stable isotope, hormone, mammal, turtle, cetacean, pinnipedia, marine

\section{INTRODUCTION}

Threats to marine megafauna continue to multiply, and management of these top predators is complex, challenging, and costly. Some threats are relatively visible (e.g., ship strikes or decreased sea ice), whereas others are more cryptic (e.g., ocean noise or climate change). Even the most visible instances of natural or anthropogenic impacts are exceedingly difficult to quantify and the population-level consequences for both lethal and non-lethal factors are usually unknown (Taylor et al., 2000; Read, 2008; Robards et al., 2009). Despite substantial research effort to monitor populations through traditional survey methods, major declines in population abundance 
are likely to go undetected (Taylor et al., 2007). To date, most management actions are not proactive, but rather occur after a deleterious or catastrophic event (e.g., Deepwater Horizon oil spill or an unusual mass mortality event) when it is often too late for feasible corrective options. Additionally, effects from climate change pose a current and emerging threat with complex and varied consequences, which can be difficult to predict (Cai et al., 2014; Stock et al., 2014). Given the multitude of risks facing marine megafauna and the limitations of current management practices, there is an ever-increasing need to understand responses of these taxa to natural stressors and to anthropogenic activities (National Academies of Sciences, Engineering, and Medicine, 2017).

Stable isotope and hormone analyses are two minimally invasive methods that may allow for finer-scale characterization of the severity, types, and consequences of megafaunal responses to their changing environment. These methods use integrated physiological biomarkers that can provide insight on the health, stress, nutrition, movements, and reproduction of individuals and populations. Such information can provide early warning signs or more in-depth information on the ecological and conservation status of marine megafauna. Consequently, biologists can use these techniques in tandem to better target strategies and timing for intervention, resulting in more anticipatory species management.

\section{Stable Isotope Ecogeochemistry}

Analyses of stable carbon $\left(\delta^{13} \mathrm{C}\right)$ and nitrogen $\left(\delta^{15} \mathrm{~N}\right)$ isotope ratios of bulk tissues from marine organisms are used to reconstruct habitat use and trophic ecology of animals that are typically cryptic, difficult to monitor, and wide-ranging in their migration and movement patterns (e.g., Kurle and Gudmundson, 2007; Newsome et al., 2010; Authier et al., 2012a; Turner Tomaszewicz et al., 2017). These analyses are informative because the $\delta^{13} \mathrm{C}$ and $\delta^{15} \mathrm{~N}$ values from bulk tissues reflect the underlying biogeochemistry driving the stable isotope values in the primary production at the base of the food web (Peterson and Fry, 1987; Trueman et al., 2012; Lorrain et al., 2014). In addition, internal physiological processes in the consumer result in their $\delta^{15} \mathrm{~N}$ values increasing predictably relative to those from their prey (Post, 2002; Kurle et al., 2014), and these differences, or trophic discrimination factors, allow for estimations of animal trophic position (DeNiro and Epstein, 1981; McMahon et al., 2015c). The stable isotope values, usually $\delta^{13} \mathrm{C}$ and $\delta^{15} \mathrm{~N}$, from consumer and prey, can be plotted in bivariate space or incorporated into various stable isotope mixing models, to create a picture of population- or species-level isotopic niche space ("isospace"), which allows for a better understanding of an organism's ecological niche (Figure 1; Newsome et al., 2007b; Stock et al., 2018).

\section{Hormones}

Recent developments in hormone analysis provide critical insights into aspects of marine megafauna biology, ecology, and population health that have previously been nearly impossible to obtain. Assessing the impacts of stressors on marine species is often limited to counts of dead or injured animals, with

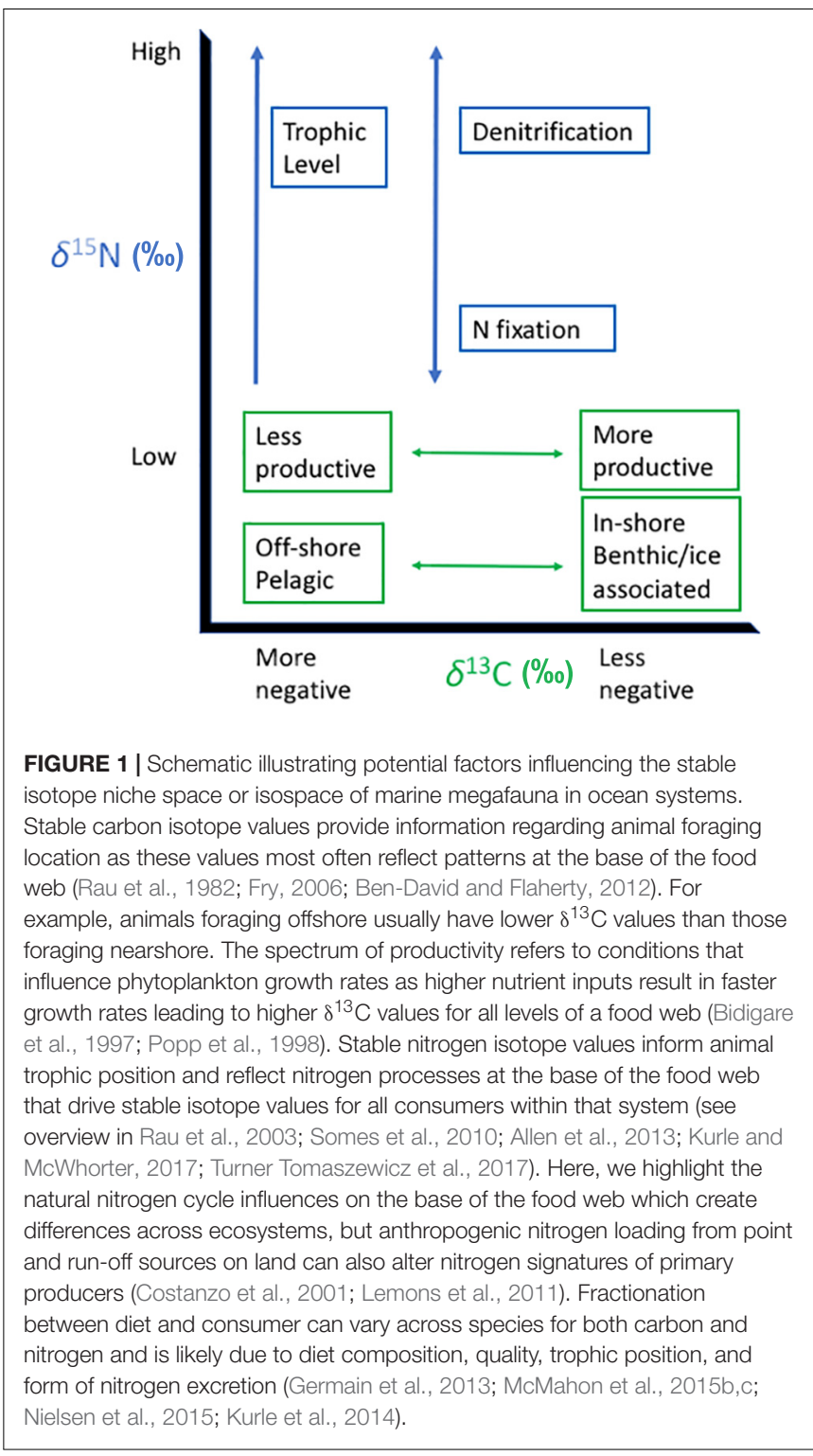

an understanding that data collected from these individuals represent a small unknown fraction of the total population and may be biased toward those experiencing extreme stress. In this way, hormone analysis of samples collected from freeranging individuals may provide earlier awareness of damaging effects and more direct evidence of relationships between stressors, and increases in dead or injured animals. Specifically, reproductive hormones can reveal an animal's sex, maturity, and pregnancy status, enabling interpretations of demographic structure, birth rates, and sex ratios, as well as the potential to assess lost or infrequent pregnancies due to exposure to harmful conditions (e.g., Rolland et al., 2012; Schwacke et al., 2014; Kellar et al., 2017). Corticosteroid hormones ("stress hormones") can elucidate both acute (e.g., ephemeral predator exposure) and chronic conditions (e.g., nutritional deficits) (e.g., Sheriff et al., 2011), whereas thyroid hormones provide 
additional information about nutritive state (e.g., Atkinson et al., 2015).

Our paper (1) briefly summarizes the contributions of stable isotope and endocrine analyses to marine megafauna conservation and management to date and the emerging and developing applications of these methods, (2) identifies opportunities for the combination of these methods, which may reveal exciting new insights into the physiology, ecology, and conservation of these species, and (3) outlines gaps and future work required to advance these fields. In this review, we restrict our discussion of marine megafauna to cetaceans, pinnipeds, and sea turtles.

\section{STABLE ISOTOPE ECOGEOCHEMISTRY IN MARINE MEGAFAUNA RESEARCH}

\section{Applications of Stable Isotope Analyses}

Estimating animal trophic levels and foraging locations has been the classic application of stable isotope data measured in animal tissues for ecological purposes (DeNiro and Epstein, 1978, 1981; Hobson and Welch, 1992). The development of progressively more sophisticated analytical methods, such as stable isotope mixing models (SIMMs) that incorporate multiple parameters, including stable isotopes of elements besides carbon and nitrogen such as sulfur, oxygen, and hydrogen, have allowed for increasingly detailed estimations of animal ecological niche space using stable isotope data (Jackson et al., 2011; Newsome et al., 2012; Hopkins and Kurle, 2016; Rossman et al., 2016; Bowes et al., 2017; Hopkins et al., 2017). There now exist a wide array of modeling frameworks and metrics for categorizing diet, trophic niche, and trophic structure (Bearhop et al., 2004; Layman et al., 2007; Jackson et al., 2011; Newsome et al., 2012; Stock et al., 2018).

Questions of competition and resource partitioning, foraging plasticity, and maternal provisioning have also been investigated with stable isotope methods (Borrell et al., 2006; Kiszka et al., 2010; Fernández et al., 2011; Authier et al., 2012b; Ryan et al., 2013). Ryan et al. (2013) found evidence of resource partitioning amongst sympatric species of rorquals (Balaenopteridae) in the North Atlantic through analysis of baleen isotopes, while Authier et al. (2012b) investigated impacts of maternal feeding strategy on pup weaning mass in southern elephant seals (Mirounga leonine). Stable isotope analyses have also illuminated population structure, examining ecological and trophic differences within species (Witteveen et al., 2009a,b; Barros et al., 2010; Lowther and Goldsworthy, 2011; Giménez et al., 2013). For example, carbon, nitrogen, and sulfur isotopes were used to differentiate putative population groups of bottlenose dolphins (Tursiops truncatus) off Florida (Barros et al., 2010) and carbon and nitrogen distinguished both breeding and feeding groups of humpback whales (Megaptera novaeangliae) in the North Pacific (Witteveen et al., 2009a,b).

Expansion of the ecological applications of stable isotope analyses have allowed for reconstructions of temporal and spatial variations in animal habitat use as species move along migration routes or target specific feeding grounds throughout multiple life stages (Hobson, 1999; Kurle, 2009; Vander Zanden et al., 2010; Authier et al., 2012c; Allen et al., 2013; Carlisle et al., 2014). For example, Turner Tomaszewicz et al. (2017) analyzed the $\delta^{15} \mathrm{~N}$ values from individual growth rings in humerus bones collected from dead-stranded North Pacific loggerhead turtles (Caretta caretta) to demonstrate their use of both oceanic and neritic regions during their decades-long stage as juveniles. The analyses of archived tissues allow for expanded temporal reconstructions of animal diets and habitat use on the order of decades or longer (Newsome et al., 2007a; Fleming et al., 2016). Fleming et al. (2016) linked environmental variability in the California Current System to variations in humpback whale diets over 20 years using isotope values from whale skin. However, temporal and spatial investigations of predator diet and trophic level can be complicated by isotopic changes at the base of the food web, which vary by region, season, and year (Kurle et al., 2011). Thus, the degree of baseline variability must be considered, and ideally estimated from lower trophic level sampling, before interpretations of predator ecologies and movements are drawn (Lorrain et al., 2014; Kurle and McWhorter, 2017).

\section{Compound Specific Stable Isotope Analysis}

More recently, advances in compound specific stable isotope analysis of individual amino acids (CSIA-AA) allow for more thorough explorations of trophic level and foraging location than bulk stable isotope analyses. CSIA-AA enables differentiation between isotopic variation due to different biochemical processes at the base of the food web versus changes in a consumer's trophic level (Popp et al., 2007; Chikaraishi et al., 2009; RuizCooley and Gerrodette, 2012; Lorrain et al., 2014; Ruiz-Cooley et al., 2014; O'Connell, 2017). Thus, even without stable isotope values from temporally or spatially linked lower trophic level organisms, temporal and spatial shifts in predator diet can often be determined. The $\delta^{15} \mathrm{~N}$ values from so-called "source" amino acids (essential amino acids for $\delta^{13} \mathrm{C}$ ) show little change or isotopic fractionation as they are transferred up the food web, whereas other "trophic" amino acids (non-essential amino acids for $\delta^{13} \mathrm{C}$ ) fractionate with increasing trophic level. Comparison of the isotope values from these two categories of amino acids allows for more nuanced interpretation of stable isotope data. This emerging technique has made most use of the $\delta^{15} \mathrm{~N}$ values from amino acids (Sherwood et al., 2011; McMahon et al., 2015a), but ecological applications for the $\delta^{13} \mathrm{C}$ values from amino acids are becoming more apparent, especially for delineating amino acid sources in diets of consumers (Larsen et al., 2009, 2013; Nielson and Winder, 2015). While measurements of amino acid isotopes from marine megafauna are increasing (Arthur et al., 2014; Ruiz-Cooley et al., 2014, 2017; Pomerleau et al., 2017; Zupcic-Moore et al., 2017), there is a need for methodological development specific to these taxa as their unique physiologies and isotopic fractionation patterns necessitate different considerations than lower trophic level taxa (e.g., zooplankton, corals) (McMahon et al., 2015b; McMahon and McCarthy, 2016). 
The increasing use of CSIA-AA for modern and archived samples will allow for greater understanding of mechanistic links between patterns in oceanographic parameters, stable isotope geochemistry, and marine megafauna responses. Variations in the bulk $\delta^{13} \mathrm{C}$ and $\delta^{15} \mathrm{~N}$ values from marine species collected over time and space can be attributed to changes in oceanographic measures that are in turn driven by climatic conditions (Kurle et al., 2011; Ohman et al., 2012; Allen et al., 2013; Kurle and McWhorter, 2017). For example, higher ocean temperatures are related to less nutrient availability, which in turn correlate to slower growth rates and lower $\delta^{13} \mathrm{C}$ values for phytoplankton (Bidigare et al., 1997; Popp et al., 1998; Schell, 2000; Figure 1). CSIA-AA of archived marine samples covering longer time periods may therefore allow for reconstruction of productivity and other trends related to long-term climate patterns that may be driving oceanographic properties of interest to bottom-up control of food webs and impacts on top predators (Hückstädt et al., 2017).

\section{Physiological Considerations for Stable Isotope Applications}

The physiology and metabolism of protein utilization are important to consider when using stable isotope analysis to reconstruct foraging patterns in marine vertebrates. First, the time required for full isotopic turnover varies across tissues due to different rates of protein metabolism and can be on the order of a few days (blood plasma, liver), months (muscle, red blood cells), or longer (bones) (Kurle, 2009; Vander Zanden et al., 2015). Accretionary tissues (e.g., vibrissae, ear plugs, and tooth dentine) produce inert layers that preserve their original chemical composition and allow for serial reconstructions over multiple years or even lifetimes. Also to be considered, single tissue types can have variable turnover rates across species and within individuals. For example, sea turtles retain growth layers in cortical bone but mammalian bone remodels and, therefore, integrates multiple years of growth information (Snover et al., 2011; Riofrío-Lazo and Aurioles-Gamboa, 2013). Within the suborder Caniformia, isotopic differences were found between cortical and non-cortical bones within individuals (Clark et al., 2017). Therefore, stable isotope values from various tissues reflect different time periods during which nutrients were ingested and incorporated and should be considered when using these analyses in conjunction with hormone studies (Figure 2).

Second, animals undergoing nutritional stress must rely on their own tissue catabolism or other mechanisms to maintain function (see Elia et al., 1999; Aguilar et al., 2014; Borrell et al., 2016), and these adaptations to resource limitation or starvation can vary in their effect on the $\delta^{13} \mathrm{C}$ and $\delta^{15} \mathrm{~N}$ values in tissues. Much evidence points to an increase in the $\delta^{15} \mathrm{~N}$ values of tissues for animals undergoing protein catabolism when they are starving (Hobson et al., 1993; Polischuk et al., 2001; Cherel et al., 2005; Lohuis et al., 2007; Newsome et al., 2010; Bowes et al., 2014). In contrast, mammals that appear to rely more heavily on fat reserves or other processes that conserve protein during times of fasting appear to demonstrate decreasing or unchanging $\delta^{15} \mathrm{~N}$ values when under nutritional stress (Das et al., 2004; Lohuis et al., 2007; Gomez-Campos et al., 2011; Aguilar et al., 2014). One explanation for these inconsistencies may be related to the amount of lipid reserves stored by an organism undergoing nutritional stress, as that appears to influence the degree to which protein versus lipid is catabolized for energy (Elia et al., 1999) and can thus influence an animal's stable isotope values (Aguilar et al., 2014). For mysticetes that are capital breeders, gestation is thought to occur during periods of fasting and requires substantial protein resources. Fetal development may lead to a decrease in $\delta^{15} \mathrm{~N}$ values for the mother throughout the pregnancy as the fetus's tissues increase in their $\delta^{15} \mathrm{~N}$ values relative to the mother (Borrell et al., 2016). Therefore, it is important to consider the life history of the animal (e.g., capital vs. income breeders) and the mechanisms responsible for the potential inconsistencies in stable isotope markers for nutritional stress.

\section{APPLICATIONS OF STRESS AND REPRODUCTIVE HORMONE ANALYSES}

Only recently have hormone data been employed regularly in studies of marine vertebrate ecology and conservation. Since their discovery, these biochemicals that signal between cells and organ systems have been primarily measured in clinical settings to help assess health and reproductive conditions of individual animals. Numerous veterinary and human medical studies have created volumes of information regarding their physiological effects, biochemistry, reference ranges, and associated anomalies (Pineda et al., 2003; Melmed et al., 2016). There was significant work done in the second half of the 20th century analyzing various hormones in marine megafauna to understand their unique physiologies (Deroos and Bern, 1961; Malvin et al., 1978; Liggins et al., 1979; St. Aubin and Geraci, 1988, 1989; Hochachka et al., 1995). However, it was not until the 2000s that these analyses became more common for marine wildlife researchers to assess hormones for conservation and physiological ecology studies, and many of these efforts were aimed at establishing baselines (Mansour et al., 2002; Mashburn and Atkinson, 2004; Rolland et al., 2005; Hunt et al., 2006; Kellar et al., 2006; Blanvillain et al., 2011; St. Aubin et al., 2013). Thus, there are relatively few examples of applied studies examining links between animal hormone levels and exposure to potentially harmful human activities or environmental conditions (Rolland et al., 2012; Kellar et al., 2013; Schwacke et al., 2014; Williard et al., 2015).

The specific molecules within steroid (e.g., progesterone and cortisol) and amino-acid derived (e.g., epinephrine and thyroid hormones) hormone classes are structurally identical across most vertebrate species (Horton and Moran, 1996; Pineda et al., 2003; Melmed et al., 2016). Because of this structural similarity among diverse taxa and their stability despite a wide spectrum of harsh field collection conditions, ecology and conservation efforts to date have mostly focused on analyses of these two hormone groups. 


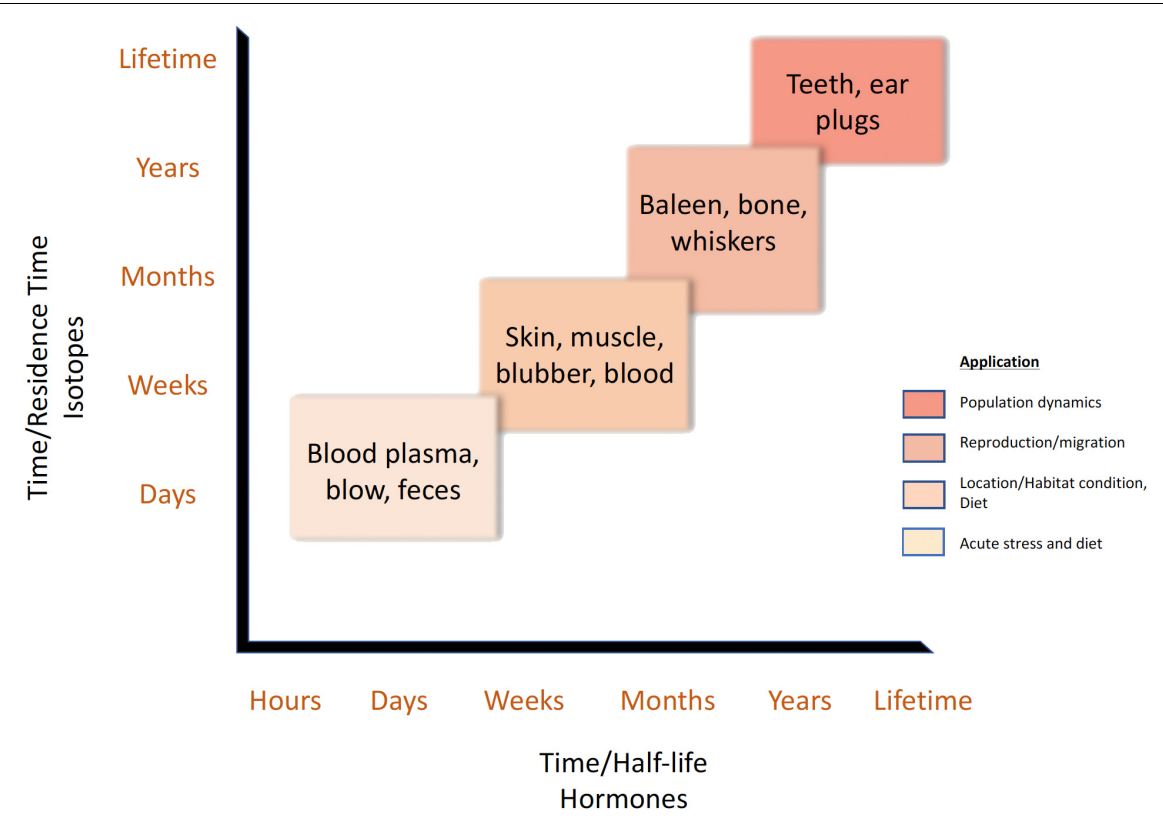

FIGURE 2 | The retention times of stable isotopes vary by tissue type as isotopic incorporation and protein turnover rates differ among tissues (Kurle, 2009). Similarly, the half-life of hormones varies across tissue type depending on each individual hormone and the matrices' chemical characteristics. This schematic illustrates the temporal scales captured by isotope or hormone analyses of multiple tissue types and some potential ecological applications of both stable isotope and hormone analyses matched to these time scales. As noted in the text, these temporal scales may vary across taxa (e.g., mammal bone vs. turtle bone).

While the specific molecules are structurally similar across taxa, their physiological roles can be quite different across both individuals and species. Additionally, interpretation of hormone levels and patterns varies by hormone type and research question. For example, measurement of hormone levels can indicate a physiological state controlled directly by the measured hormones (e.g., hormonal controls on pregnancy and maturation) (Theodorou and Atkinson, 1998; Owens, 1999; Greig et al., 2007; Kellar et al., 2009, 2014; Perez et al., 2011; Vu et al., 2015). Alternatively, hormone levels can be assessed as an indicator of direct response to some external stimuli (e.g., fightor-flight responses) (Gregory et al., 1996; St. Aubin and Dierauf, 2001; Sheriff et al., 2011). In more recent years, there has been another avenue of investigation into changes in hormone levels due to secondary or indirect responses, such as those associated with exposure to high levels of environmental contaminants (Subramanian et al., 1987; Oskam et al., 2003; Trego et al., 2018). The following paragraphs introduce the various types, applications, and interpretations of hormones most commonly used in marine megafauna research.

\section{Sample Matrices}

Marine megafauna have diverse sample matrices (tissues, body fluids, and physiological end-products) from which hormones are measured. Relative to hormone distribution patterns, the matrices can be subdivided into three types: (1) those that are in dynamic equilibrium (e.g., blood, blubber, most bone tissue, and muscle) with the hormone concentrations generated by the gland of production, (2) those that become relatively static once formed thereby potentially offering a record of previous hormone concentrations (e.g., laminated ear plugs, fur, hair, whiskers, baleen, claws, laminated bone structures, and potentially, teeth, tusks, and epidermal tissue), and (3) those that are biological end products formed then expelled (e.g., blow particulate ("whale snot"), respiratory vapor, feces, urine, saliva, egg shells, and milk). Moreover, as with stable isotopes, each matrix has its own set of dynamics, integrating signals over varying lengths of time depending on each individual hormone and the matrices' chemical characteristics (Figure 2). Note that the processing of these matrices for hormone analysis typically has two phases: (1) isolation of the target hormone and (2) analytical measurement. The measurement procedures (e.g., immunoassays, chromatography, and mass spectrophotometerbased analytical analyses) can theoretically be used with any of the matrices; however, isolation procedures vary enormously as they are tailored to each matrix's specific composition and chemistry relative to the target hormone.

\section{Progesterone}

Progesterone is a particularly informative indicator of cetacean pregnancy status, which researchers have used to estimate pregnancy rates in several populations (Bergfelt et al., 2013; Kellar et al., 2013, 2014; Clark et al., 2016). In situations where known stressors or atypical perturbations are of concern (e.g., exposure of dolphins to chase-and-encirclement fishery activity), relationships between the frequency or magnitude of exposure to these perturbations and pregnancy rates have been assessed (Kellar et al., 2013). Similarly, reproductive success rates (rates of known pregnancies producing viable calves) have been examined with respect to poor prey availability (Wasser et al., 2017) or 
exposure to pollutants (Kellar et al., 2017). Progesterone levels in pinnipeds have also been shown to aid in assessing the pregnancy state of individuals (Gardiner et al., 1996, 1999; McKenzie et al., 2005; Greig et al., 2007). However, in these species, there can be overlap in hormone concentration between known nonconceiving females and females predicted to be pregnant based on progesterone concentrations such that the diagnostic power of progesterone is more limited though still informative (McKenzie et al., 2005; Beaulieu-McCoy et al., 2017). In these animals (along with cetaceans and sea turtles), progesterone can aid in maturity state assessments of females and help elucidate estrous activity in conjunction with measurements of other hormones, like estrogens (Licht et al., 1982; Pietraszek and Atkinson, 1994; Gardiner et al., 1996, 1999; Kakizoe et al., 2010; Beaulieu-McCoy et al., 2017). Progesterone concentration has not been widely assessed in marine turtle experimental studies as this hormone is at baseline levels until a reproductively active female commences nesting activities (see overview in Blanvillain et al., 2011).

\section{Androgens}

Androgen concentrations, especially those of testosterone, have been applied in a variety of ways in marine megafauna ecology and conservation research. In marine mammals, testosterone helps assess maturity states of individual males (e.g., in blubber, Kellar et al., 2009) and, in more static matrices (e.g., laminated ear plugs), it is used to estimate ages of sexual maturation (Trumble et al., 2013). Testosterone measurements can elucidate reproductive seasonality characteristics of populations, information that can help identify time-of-year associated with heightened vulnerability to potential stressors (i.e., periods of breeding; Robeck and Monfort, 2006; Kellar et al., 2009; $\mathrm{Vu}$ et al., 2015). More generally, pollutant exposure has been linked to decreased levels of androgens, as well as estrogens, in a number of marine megafauna species creating potential impacts on development and reproduction (Subramanian et al., 1987; Oskam et al., 2003; Trego et al., 2018). Finally, androgen levels are utilized to help determine the sex of individual animals (Allen et al., 2015; Corkeron et al., 2017). This is particularly important for sea turtles as they display no genotypic markers for sex or external secondary sexual characteristics until maturation (males grow longer tails), and, because their sex is temperature dependent, monitoring sex ratios of turtle populations using testosterone can help identify potential negative impacts of changing environmental conditions on their demography (Allen et al., 2015; Braun McNeill et al., 2016; Jensen et al., 2018).

Since hormone concentrations in hatchling sea turtles are minute, the ratio of estradiol to testosterone was used to predict the sex of sacrificed, just-hatched sea turtles (Gross et al., 1995). However, advances in hormone assay technology should allow detection of hormone concentrations in small volumes of blood collected from hatchlings without deleterious effects (e.g., death or low survivorship), providing the opportunity to assess primary sex ratios for all species of sea turtles.

\section{Corticosteroids}

In marine megafauna, the dominant corticosteroids (cortisol, corticosterone, and aldosterone) serve as biochemical markers of physiological stress response activity; specifically they are most often interpreted as indicators of hypothalamic-pituitaryadrenal (HPA) axis activation in response to perceived threats (Gregory et al., 1996; St. Aubin and Dierauf, 2001; Sheriff et al., 2011). For the HPA axis, glucocorticoids (GC), cortisol and corticosterone, stimulate creation of additional glucose in anticipation of increased energy needs in response to a stressor (Palme et al., 2005; Busch and Hayward, 2009; Blanvillain et al., 2011; Atkinson et al., 2015). GC concentrations have been analyzed in numerous marine mammal and turtle species ranging from individual responses to stressors like restraint or capture of individual animals (Thomson and Geraci, 1986; St. Aubin and Geraci, 1988, 1989; Gregory et al., 1996; Champagne et al., 2012; St. Aubin et al., 2013; Williard et al., 2015; Hunt et al., 2016a), to population-level responses to increased anthropogenic activity (e.g., vessel traffic; Ayres et al., 2012; Rolland et al., 2012). Glucocorticoid concentrations also vary with temperature perturbations (Houser et al., 2011), nutritional deficits (Kellar et al., 2015; Beaulieu-McCoy et al., 2017; Wasser et al., 2017), and pollutant exposure (most notably oiling from the Deepwater Horizon disaster; Schwacke et al., 2014). These may not be stressors in the classical sense and are therefore often referred to as types of "environmental stressors" as there is not necessarily a perception of threat at an individual level. This distinction is important as these conditions do not necessarily stimulate cortisol production, especially as an anticipatory reaction, as seen in a perceived threat-to-self response (also known as a fight-or-flight response).

The other primary corticosteroid, aldosterone, mainly controls the electrolytic composition of blood to regulate blood pressure and blood volume (St. Aubin, 2001). In marine mammals, aldosterone often shows responses to known stressors that are similar to those of GCs (Thomson and Geraci, 1986; St. Aubin and Geraci, 1989; St. Aubin et al., 1996; Houser et al., 2011). A sea turtle study investigated the effects of acute fresh water exposure and found no change in aldosterone or corticosterone production and suggested that compared to marine mammals, sea turtle response to a hypo-osmotic environment might be delayed (Ortiz et al., 2000). Aldosterone often shows greater relative increases compared to cortisol, though at much lower total concentrations (St. Aubin and Geraci, 1989). It is theorized that this may be due in part to the importance of breath-hold diving (and the profound accompanying changes in blood distribution) in these animals as they respond to potential threats (Atkinson et al., 2015). These observations are creating new interest in using aldosterone as another marker of stress, and, though few studies have examined aldosterone levels relative to known stressors outside of experimental settings, this will likely change in the near future.

\section{Thyroid Hormones}

Along with GC levels, thyroid hormones (thyroxine, T4 and triiodothyronine, T3) can help in the assessment of individual and population-level nutritional conditions (Atkinson et al., 2015). T4 is a prohormone and typically is converted to T3, the active form, to directly bind to receptors and produce biological effects (St. Aubin, 2001; Melmed et al., 2016). These effects 
help control entire metabolic rates of individuals by regulating numerous metabolic pathways. Limited food intake generally inhibits the production and activity of thyroid hormones, especially T3 (Pineda et al., 2003; Melmed et al., 2016). This works by (1) blocking the conversion of T4 to T3 and (2) by stimulating the conversion of both to another form, "reverse T3" (rT3). In this form, rT3 still binds to T3 receptors, but produces no biological effects thereby blocking the associated pathways and lowering the overall metabolic rate (Horton and Moran, 1996; Pineda et al., 2003). Though a number of studies have looked at the effects of food limitations on the thyroid concentrations of individuals (Moon et al., 1998, 1999; Rosen and Trites, 2002; Rosen and Kumagai, 2008; du Dot et al., 2009), few have used thyroid hormone measurements to help assess the populationlevel impacts of limited prey availability in non-captive animals (Moon et al., 1998; Ayres et al., 2012; Crocker et al., 2012; Wasser et al., 2017).

\section{INTEGRATED APPLICATIONS OF STABLE ISOTOPE AND HORMONE ANALYSES}

In addition to the established and emerging applications of both stable isotope and hormone analyses in marine megafauna presented above, the combination and integration of these two methods offer innumerable possibilities for academic and conservation focused research. While little has been published utilizing both methods concurrently for marine megafauna (Hunt et al., 2014, 2016b; Clark et al., 2016), there has been considerable effort on this front in seabird and terrestrial predator research fields. Using these taxa as examples, we offer a few of the major research areas and questions we foresee as productive for the intersection of these two methods and discuss how they can inform marine megafauna conservation and management efforts. Three major research areas have utilized a combination of these two methods: (1) nutrition and health, (2) reproduction, and (3) life history. We identify a fourth area of research, examinations of evolutionary versus ecological drivers of behavior, that could also be well served by a combined stable isotope and hormone analyses approach.

\section{Nutrition and Health}

Numerous external influences on marine megafauna can impact nutrition and health, including changes in prey availability and/or quality, degraded or inconsistent habitat conditions (due to natural variability or anthropogenic factors), competition, disease, and direct anthropogenic impacts such as entanglement, ocean noise, or ship strikes. To date, the research effort combining stable isotope and hormone analyses has focused largely on the impacts of variable prey and habitat conditions (e.g., Barger and Kitaysky, 2011; Dorresteijn et al., 2012; Bryan et al., 2013, 2014; Lafferty et al., 2015; Boggs et al., 2016). As top predators, marine megafauna depend on abundant prey and/or dense prey patches and they often capitalize on regions of reliably high biological productivity (Hazen et al., 2009;
Santora et al., 2011). However, these areas are subject to climatedriven environmental fluctuations that affect marine productivity (e.g., Macklin et al., 2002; Bograd et al., 2009; Sherwood et al., 2011; Stabeno et al., 2012), contributing to the potential for episodic inadequate prey resources for megafauna that can induce stress, increase competition, create nutritional deficits, and lead to potential starvation. Understanding the linkages between climate, habitat, prey availability, and marine mammal diets, and predicting how these variables impact megafauna conservation and management, is increasingly important in the face of ongoing warming (e.g., Howard et al., 2013).

Currently, the influence of climate change on prey availability for top ocean predators is a topic of considerable research effort across various temporal scales (Wolf et al., 2010). To understand the impacts of current and future changes in climate on marine megafauna, analyses of interannual and decadal patterns are often used as proxies to better understand and predict future population responses to long-term change. For example, Dorresteijn et al. (2012) examined impacts of interannual climate variability and timing of ice retreat on food availability for least auklets (Aethia pusilla), a seabird in the Bering Sea. They combined assessment of changes in auklet diet as measured by stable isotope analyses and regurgitated chick meals with changes in the stress hormone, corticosterone, in auklet blood to assess food availability (higher levels of corticosterone are associated with lower food availability). The combination of isotope, regurgitate, and hormone analyses revealed a more in-depth understanding of the species response than any method in isolation, as two different colonies were found to respond differently to the changing climatic and oceanographic conditions. Only one colony showed changes in diet, but both colonies showed increased levels of corticosterone during warm periods, indicating that, while the diet may not have changed for both colonies, the relative foraging effort may have (Dorresteijn et al., 2012). Such insights are particularly helpful in a management context as they provide further metrics of the consequences of environmental changes on top predators.

The combination of stable isotope and hormone analyses has also been utilized to examine the interplay of intra- and interspecies competition in relation to changing prey conditions. Barger and Kitaysky (2011) demonstrated increasing dietary separation (assessed by stable isotopes) among two species of sympatric seabirds (Uria spp.) in response to food limitation (supported by increasing concentrations of stress hormone) and greater niche overlap when food was abundant. Within-species resource competition was investigated by Bryan et al. (2014) in grizzly (Ursus arctos) and black bears (Ursus americanus) in the Pacific northwest through stable isotope Bayesian mixing models and surveys of salmon (Oncorhynchus spp.) abundance. In grizzly bears, cortisol increased in response to lower salmon consumption. However, in black bears, cortisol increased in response to lower salmon availability, which was tightly coupled to increased competition, indicating a stronger link to social competition in black bears. In both bear species, testosterone decreased with increasing salmon availability, which the authors interpreted as evidence of a less competitive environment. Consequences of diet quality can also be investigated with a 
combination of hormone and stable isotope analyses. Fairhurst et al. (2015) found that feathers from Leach's storm petrels (Oceanodroma leucorhoa) with higher $\delta^{15} \mathrm{~N}$ values, an indication they were foraging at higher trophic levels, were associated with correspondingly lower corticosterone concentrations. Their data suggested a physiological benefit in the form of either a reduced foraging effort or a greater nutrient benefit associated with consumption of higher trophic level prey by the petrels.

Further research directions on this topic could include investigations of health conditions that may be distinct from dietary inadequacies but could be mistaken for responses to nutritional stress without more detailed data. For example, energetic and endocrine responses to diseases resulting from ecotoxicological or immunological factors may also be aided by a combination of hormone and stable isotope analyses. While most diseases in the wild may have a nutritional component, there may be some instances of direct links to a disease or injury stressor that may not be primarily mediated through prey or nutritional stress. In these cases, assessing both hormone levels and stable isotope values can allow biologists to rule out biologists to rule out the potential for interactions between health and diet.

\section{Reproduction}

Reproductive behavior, biology, and rates are exceptionally challenging to study in marine megafauna and, for many species, the oceanic habitats in which these animals breed remain unknown (Robeck et al., 2001; Blanvillain et al., 2011). For taxa with more visible reproductive behaviors, such as sea turtles and pinnipeds, there has been substantial examination of hormone levels and patterns. However, we are aware of little research combining hormone and stable isotope analyses for better deciphering questions related to reproduction in other marine species. One of the most fundamental research topics that can be developed by the integration of these two methodologies is baseline physiological patterns inherent to particular reproductive or life history stages. For example, does an individual's ontogenetic stage influence diet and stress or diet and reproductive endocrinology? Do the diverse metabolic needs required at different reproductive or life stages lead to different prey preferences or foraging efforts? Addressing these questions will develop critical baselines from which other, more acute, questions can be added.

Some investigations into reproductive questions using both stable isotope and hormone analyses interpreted these analyses separately, whereas others drew integrated conclusions. Both approaches can add value to single discipline studies, however, we encourage future research to consider the interactions and background physiological conditions that may be driving both the hormonal and stable isotope patterns. For example, Hunt et al. (2016b) examined cortisol and corticosterone changes along baleen plates from two female right whales (Eubalaena glacialis) in relation to observed life stage/reproductive events. They used stable isotope values to demarcate time along the baleen plate, as these values change predictably with annual migration cycles, but they did not consider the potential interplay between hormone and stable isotope values. They found that corticosterone was elevated during pregnancy and lactation, whereas cortisol had more variable, brief spikes along the temporal record, suggesting the two glucocorticoids react differently to stressors. Clark et al. (2016) investigated humpback whale hormones and stable isotope values throughout two feeding seasons to examine pregnancy rates and the impact of pregnancy on stable isotope values and found that pregnant females showed different isotope values than males or non-pregnant females. This potentially reflects changes in tissue synthesis, increased use of lipid stores, and reduced excretion of nitrogenous waste, allowing for a proposed model of predictable changes in hormone levels and corresponding stable isotope values over the life of reproductive female humpback whales.

Bird studies have made considerable progress combining hormone and stable isotope analyses, especially to examine the influence of provisioning on reproductive parameters. For example, Barger et al. (2016) found that sympatric species of murres (Uria spp.) changed their foraging behavior by traveling to different areas to forage for alternative prey during the energetically demanding periods of reproduction (incubation and chick-rearing) to possibly reduce competition. Tartu et al. (2014) found that luteinizing hormone may be impacted by mercury load which was in turn influenced by diet and age in snow petrels (Pagodroma nivea). Their findings support previous research that mercury reduce luteinizing hormone, thereby decreasing reproductive fitness, especially in long-lived birds (Tartu et al., 2013; Goutte et al., 2014). Kouwenberg et al. (2013) found that elevated corticosterone promoted foraging during molt in puffins (Fratercula arctica) which led to consumption of higher trophic level diet and increased egg mass during reproduction.

Further research in this area could combine assessments of body condition, stable isotope values, and hormone concentrations in marine megafauna. For example, photogrammetric information on body condition in cetaceans and pinnipeds could be related to reproductive stage, isotopic niche, and concentrations of stress hormones. Availability of food resources for sea turtles could be examined in relation to nesting frequency and reproductive output. Since various reproductive stages are nutritionally demanding, combining stable isotopes with both stress and reproductive hormone analyses may provide greater insight on the extent of fat storage utilization and nutritional condition throughout pregnancy and lactation. These methodological combinations would enable interesting comparisons across income and capital breeders.

\section{Life History}

Marine megafauna have complex and varied life history patterns accompanied by specific physiological adaptations and behaviors evolved to support these life histories. For example, longdistance annual migrations are common amongst many taxa. Yet, unraveling the specific determinants of these migrations has long been a subject of much research and speculation. Diet, hormones, offspring protection, thermal regulation, and other factors are all potential contributors to the complex process of migration (Brodie, 1975; Corkeron and Connor, 1999; Clapham, 2001), and the combination of stable isotope and hormone analyses has been used to better understand drivers of migration, especially 
in birds. For instance, Warne et al. (2015) examined potential determinants of migratory timing in saw-whet owls (Aegolius acadicus). They used stable oxygen $\left(\delta^{18} \mathrm{O}\right)$ or $\delta$ deuterium $\left(\delta^{2} \mathrm{H}\right)$ isotope values to indicate location or arrival of owls on breeding grounds, and they observed that corticosterone was elevated in birds that migrated earlier. Higher corticosterone levels in owl feathers and blood were related to increased foraging and migratory preparedness/body condition which presumably contributed to the early onset of migration in certain owls. Covino et al. (2017) found that in combining analyses of stable hydrogen isotope values, which indicate proximity to breeding grounds, with testosterone concentrations, which correlate with increased breeding preparation, they were able to decipher the timing of breeding preparedness in male songbirds (Mniotilta varia) in relation to their long-distance migrations. During migration, these birds must devote energy to the journey, as well as toward development of breeding characteristics that prepare them for reproduction when they arrive at the breeding ground. The $\delta^{2} \mathrm{H}$ values indicated that male songbird testosterone levels increased as they approached the breeding area, whereas the reproductive schedule for female songbirds did not show such geographically linked timing and requires further exploration.

For many species of migratory marine megafauna, the ability to fast for half the year is routine. Such fasting requires extreme physiological adaptations that are currently poorly understood and that could be greatly informed via combined hormone and stable isotope analyses. Additionally, differences in physiological responses that occur in animals evolved to experience routine (e.g., migratory) fasting versus those forced to endure unexpected and catastrophic fasting (e.g., declining productivity experienced in certain marine systems during climate-induced warming events) could be investigated through these combined methods. For example, elevated $\delta^{15} \mathrm{~N}$ values and corresponding high cortisol levels measured in blood from starving animals may indicate more extreme nutritional stress, whereas lower $\delta^{15} \mathrm{~N}$ values and higher cortisol levels may indicate normal fasting conditions in a migratory capitol breeder. In the marine environment, stable oxygen $\left(\delta^{18} \mathrm{O}\right)$, or $\delta$ deuterium $\left(\delta^{2} \mathrm{H}\right)$ isotope values can provide additional gradients for tracking movements in the ocean, especially between coastal and offshore habitats, and polar and temperate latitudes (McMahon et al., 2013; MacAvoy et al., 2017). In polar regions, the inclusion of $\delta^{2} \mathrm{H}$ may correlate to sea ice concentration (deHart and Picco, 2015), offering opportunities to examine migration, sea ice conditions, and stress by combining stable isotope and hormone analyses. Finally, it should be mentioned that other technological tools, such as biologging and tagging devices, are natural complements to stable isotope and hormone analyses for the study of migration and life history.

\section{Evolutionary and Ecological Drivers}

In addition to the above areas of research, the subject of evolutionary versus ecological determinants of population parameters and behavior might also be explored with the combination of stable isotopes and hormone analyses. Yet, to our knowledge, nothing on this subject has been published thus far. We suggest that future studies examine questions that begin to address the topic of plasticity. For example, when resources change, do individuals alter their reproductive or movement behaviors in order to adapt to the new conditions or do they maintain behaviors because they have evolved to do so? When a population is declining or increasing, do they respond differently to changes in their environment? Such questions are often very challenging to address with observational data. Yet the integration of hormone analyses and stable isotope methods, along with other established and emerging population metrics, may enable exploration of reproductive and ecological responses to both external and internal drivers. Improved understanding of individual and population responses to change would be a valuable asset to conservation and management efforts.

\section{CONCLUSION AND NEXT STEPS}

Combined investigations using stable isotopes and hormones could address questions at a variety of biological levels, progressing from external (e.g., changes in habitat conditions or prey availability) to internal (e.g., physiological) and individual

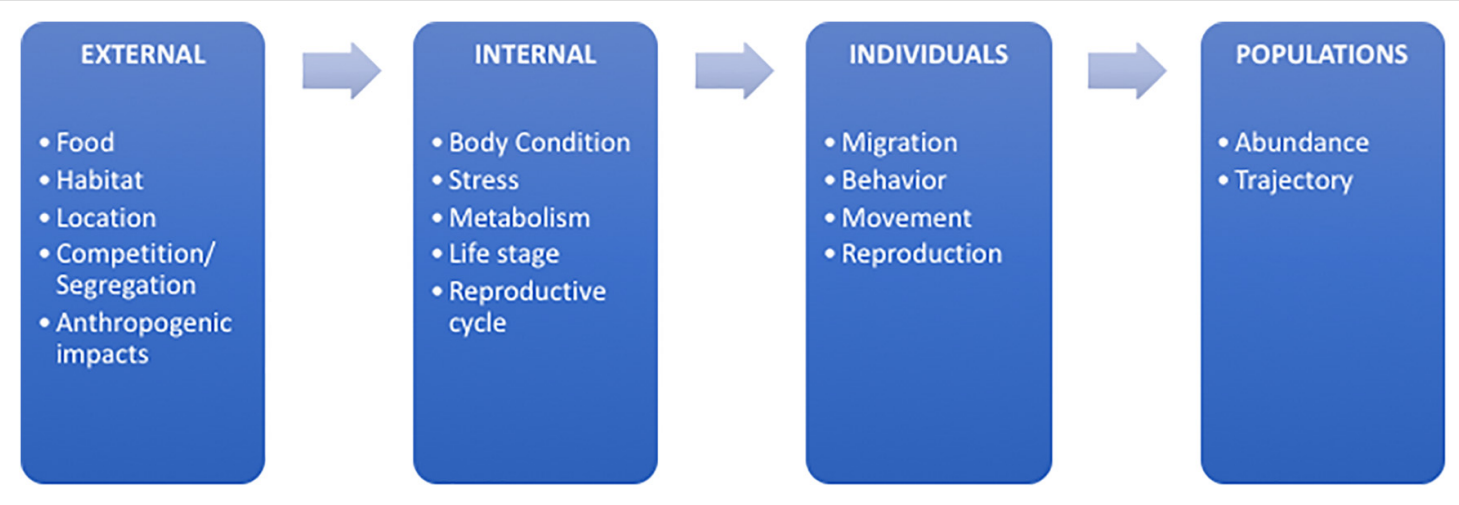

FIGURE 3 | Summary schematic of the numerous current and future research topics that could be further developed with the combination of stable isotope and hormone analyses. The schematic is organized by biological level progressing from external variables impacting marine megafauna, to internal physiological drivers, then to topics relating to individual animals as well as population-level investigations. 
(e.g., reproduction or migration) to population-level responses (e.g., population abundance) (Figure 3). The combination of these analyses in studies of marine megafauna can allow for layering of multiple questions and lines of evidence to inform management decisions or conservation issues. Each of these broad areas of research (Figure 3) will require methodological developments as the ecological, evolutionary, and life history investigations evolve.

While there is a suite of methodological developments that would be useful (e.g., further research on storage considerations that enable both types of analyses on the same tissue, etc.), there is one major topic that should be the focus of nearterm efforts to develop this field. More methodological research is needed to enable the successful temporal alignment of these two analytical techniques. For example, while hormones have dedicated metabolic pathways that control their halflife and concentration in each tissue type, stable isotopes are metabolized coincident with the tissue they are in. Thus, these two markers are both subject to, and reflect different physiological processes and time scales which complicate attempts to evaluate them in parallel. Consequently, research is needed on the durations, amplitudes, and incorporation rates of each signal compared to the other, across multiple matrices.

\section{REFERENCES}

Aguilar, A., Giménez, J., Gómez-Campos, E., Cardona, L., and Borrell, A. (2014). $\delta 15 \mathrm{~N}$ value does not reflect fasting in mysticetes. PLoS One 9:e92288. doi: 10.1371/journal.pone.0092288

Allen, C. D., Lemons, G. E., Eguchi, T., LeRoux, R. A., Fahy, C. C., Dutton, P. H., et al. (2013). Stable isotope analysis reveals migratory origin of loggerhead turtles in the Southern California Bight. Mar. Ecol. Prog. Ser. 472, 275-285. doi: $10.3354 /$ meps 10023

Allen, C. D., Robbins, M. N., Eguchi, T., Owens, D. W., Meylan, A. B., Meylan, P. A., et al. (2015). First assessment of the sex ratio for an East Pacific green sea turtle foraging aggregation: validation and application of a testosterone ELISA. PLoS One 10:e0138861. doi: 10.1371/journal.pone.0138861

Arthur, K. E., Kelez, S., Larsen, T., Choy, C. A., and Popp, B. N. (2014). Tracing the biosynthetic source of essential amino acids in marine turtles using $813 \mathrm{C}$ fingerprints. Ecology 95, 1285-1293. doi: 10.1890/13-0263.1

Atkinson, S., Crocker, D. E., Houser, D. S., and Mashburn, K. (2015). Stress physiology in marine mammals: how well do they fit the terrestrial model? J. Comp. Physiol. B 185, 463-486. doi: 10.1007/s00360-015-0901-0

Authier, M., Bentaleb, I., Ponchon, A., Martin, C., and Guinet, C. (2012a). Foraging fidelity as a recipe for a long life: foraging strategy and longevity in male Southern elephant seals. PLoS One 7:e32026. doi: 10.1371/journal.pone.0032026

Authier, M., Dragon, A.-C., Richard, P., Cherel, Y., and Guinet, C. (2012b). O' mother where wert thou? Maternal strategies in the southern elephant seal: a stable isotope investigation. Proc. Biol. Sci. 279, 2681-2690. doi: 10.1098/rspb. 2012.0199

Authier, M., Martin, C., Ponchon, A., Steelandt, S., Bentaleb, I., and Guinet, C. (2012c). Breaking the sticks: a hierarchical change-point model for estimating ontogenetic shifts with stable isotope data. Methods Ecol. Evol. 3, 281-290. doi: 10.1111/j.2041-210X.2011.00162.x

Ayres, K. L., Booth, R. K., Hempelmann, J. A., Koski, K. L., Emmons, C. K., Baird, R. W., et al. (2012). Distinguishing the impacts of inadequate prey and vessel traffic on an endangered killer whale (Orcinus orca) population. PLoS One 7:e36842. doi: 10.1371/journal.pone.0036842

Barger, C. P., and Kitaysky, A. S. (2011). Isotopic segregation between sympatric seabird species increases with nutritional stress. Biol. Lett. 8, 442-445. doi: $10.1098 / \mathrm{rsbl} .2011 .1020$
Quantification of the amounts of each incorporated marker, their detectable levels, and the recording rate of each marker will require controlled experiments. Researchers with access to captive animals or large archival collections, such as those in museums and zoological collections, are aptly poised to develop such investigations. These will be pivotal to conservation and management applications of integrated hormone and stable isotope techniques.

\section{AUTHOR CONTRIBUTIONS}

AF led study design. All authors were involved in manuscript research, writing, figure preparation, and review of final drafts.

\section{FUNDING}

Funding was provided by the Smithsonian Institution's James Smithson Postdoctoral Fellowship Program, the Smithsonian Institution Women's Committee, the University of California, San Diego, and the Office of Naval Research Grant \#N0001417IP00068.

Barger, C. P., Young, R. C., Will, A., Ito, M., and Kitaysky, A. S. (2016). Resource partitioning between sympatric seabird species increases during chick-rearing. Ecosphere 7:e01447. doi: 10.1002/ecs2.1447

Barros, N. B., Ostrom, P. H., Stricker, C. A., and Wells, R. S. (2010). Stable isotopes differentiate bottlenose dolphins off west-central Florida. Mar. Mamm. Sci. 26, 324-336. doi: 10.1111/j.1748-7692.2009.00315.x

Bearhop, S., Adams, C. E., Waldron, S., Fuller, R. A., and Macleod, H. (2004). Determinding trophic niche width: a novel approach using stable isotope analysis. J. Anim. Ecol. 73, 1007-1012. doi: 10.1111/j.0021-8790.2004.00861.x

Beaulieu-McCoy, N. E., Sherman, K. K., Trego, M. L., Crocker, D. E., and Kellar, N. M. (2017). Initial validation of blubber cortisol and progesterone as indicators of stress response and maturity in an otariid; the California sea lion (Zalophus californianus). Gen. Comp. Endocrinol. 252, 1-11. doi: 10.1016/ j.ygcen.2017.07.003

Ben-David, M., and Flaherty, E. (2012). Stable isotopes in mammalian research: a beginner's guide. J. Mammal. 93, 312-328. doi: 10.1644/11-MAMM-S-166.1

Bergfelt, D. R., Steinetz, B. G., Reif, J. S., Schaefer, A. M., Bossart, G. D., Mazzoil, M. S., et al. (2013). Evaluation of single-sample analysis of progesterone in combination with relaxin for diagnosis of pregnancy in wild bottlenose dolphins (tursiops truncatus). Aquat. Mamm. 39, 187-195. doi: 10.1578/AM. 39.2.2013.187

Bidigare, R. R., Fluegge, A., Freeman, K. H., Hanson, K. L., Hayes, J. M., Hollander, D., et al. (1997). Consistent fraction of 13C in nature and in the laboratory: growth-rate effects in some haptophyte algae. Global Biogeochem. Cycles 11, 279-292. doi: 10.1029/96GB03939

Blanvillain, G., Owens, D. W., and Kuchling, G. (2011). "Hormones and reproductive cycles in turtles," in Hormones and Reproduction of Vertebrates, Vol. 3, ed. D. O. Norris (New York, NY: Elsevier Inc.), 277-303.

Boggs, A. S. P., Hamlin, H. J., Nifong, J. C., Kassim, B. L., Lowers, R. H., Galligan, T. M., et al. (2016). Urinary iodine and stable isotope analysis to examine habitat influences on thyroid hormones among coastal dwelling American alligators. Gen. Comp. Endocrinol. 226, 5-13. doi: 10.1016/j.ygcen.2015.12.006

Bograd, S. J., Schroeder, I., Sarkar, N., Qiu, X., Sydeman, W. J., and Schwing, F. B. (2009). Phenology of coastal upwelling in the California current. Geophys. Res. Lett. 36:L01602. doi: 10.1029/2008GL035933

Borrell, A., Aguilar, A., Tornero, V., Sequeira, M., Fernandez, G., and Alis, S. (2006). Organochlorine compounds and stable isotopes indicate bottlenose 
dolphin subpopulation structure around the Iberian Peninsula. Environ. Int. 32, 516-523. doi: 10.1016/j.envint.2005.12.001

Borrell, A., Gómez-Campos, E., and Aguilar, A. (2016). Influence of reproduction on stable-isotope ratios: nitrogen and carbon isotope discrimination between mothers, fetuses, and milk in the fin whale, a capital breeder. Physiol. Biochem. Zool. 89, 41-50. doi: 10.1086/684632

Bowes, R. E., Lafferty, M. H., and Thorp, J. H. (2014). Less means more: nutrient stress leads to higher $\delta 15 \mathrm{~N}$ ratios in fish. Freshw. Biol. 59, 1926-1931. doi: $10.1111 /$ fwb. 12396

Bowes, R. E., Thorp, J. H., and Reuman, D. C. (2017). Multidimensional metrics of niche space for use with diverse analytical techniques. Sci. Rep. 7:41599. doi: $10.1038 /$ srep 41599

Braun McNeill, J., Avens, L. A., Goodman Hall, A., Goshe, L. R., Harms, C. A., and Owens, D. W. (2016). Female-bias in a long-term study of a species with temperature-dependent sex determination: monitoring sex ratios for climate change research. PLoS One 11:e0160911. doi: 10.1371/journal.pone.0160911

Brodie, P. F. (1975). Cetacean energetics, an overview of intraspecific size variation. Ecology 56, 152-161. doi: 10.2307/1935307

Bryan, H. M., Darimont, C. T., Paquet, P. C., Wynne-Edwards, K. E., and Smits, J. E. G. (2013). Stress and reproductive hormones in grizzly bears reflect nutritional benefits and social consequences of a salmon foraging niche. PLoS One 8:e80537. doi: 10.1371/journal.pone.0080537

Bryan, H. M., Darimont, C. T., Paquet, P. C., Wynne-Edwards, K. E., and Smits, J. E. G. (2014). Stress and reproductive hormones reflect inter-specific social and nutritional conditions mediated by resource availability in a bear-salmon system. Conserv. Physiol. 2:cou010. doi: 10.1093/conphys/cou010

Busch, D. S., and Hayward, L. S. (2009). Stress in a conservation context: a discussion of glucocorticoid actions and how levels change with conservationrelevant variables. Biol. Conserv. 142, 2844-2853. doi: 10.1016/j.biocon.2009.0 8.013

Cai, W., Borlace, S., Lengaigne, M., van Rensch, P., Collins, M., Vecchi, G., et al. (2014). Increasing frequency of extreme El Niño events due to greenhouse warming. Nat. Clim. Chang. 4, 111-116. doi: 10.1038/nclimate2100

Carlisle, A. B., Goldman, K. J., Litvin, S. Y., Madigan, D. J., Bigman, J. S., Swithenbank, A. M., et al. (2014). Stable isotope analysis of vertebrae reveals ontogenetic changes in habitat in an endothermic pelagic shark. Proc. R. Soc. B 282:20141446. doi: 10.1098/rspb.2014.1446

Champagne, C. D., Houser, D. S., Costa, D. P., and Crocker, D. E. (2012). The effects of handling and anesthetic agents on the stress response and carbohydrate metabolism in northern elephant seals. PLoS One 7:e38442. doi: 10.1371/ journal.pone. 0038442

Cherel, Y., Hobson, K. A., Baiileul, F., and Groscolas, R. (2005). Nutrition, physiology, and stable isotopes: new information from fasting and molting penguins. Ecology 86, 2881-2888. doi: 10.1890/05-0562

Chikaraishi, Y., Ogawa, N. O., Kashiyama, Y., Takano, Y., Suga, H., Tomitani, A., et al. (2009). Determination of aquatic food-web structure based on compoundspecific nitrogen isotopic composition of amino acids. Limnol. Oceanogr. Methods 7, 740-750. doi: 10.1016/j.jchromb.2016.09.004

Clapham, P. (2001). Why do baleen whales migrate? Mar. Mamm. Sci. 17, 432-436. doi: 10.1111/j.1748-7692.2001.tb01289.x

Clark, C. T., Fleming, A. H., Calambokidis, J., Kellar, N. M., Allen, C. D., Catelani, K. N., et al. (2016). Heavy with child? Pregnancy status and stable isotope ratios as determined from biopsies of humpback whales. Conserv. Physiol. 4:cow050. doi: 10.1093/conphys/cow050

Clark, C. T., Horstmann, L., and Misarti, N. (2017). Quantifying variability in stable carbon and nitrogen isotope ratios within the skeletons of marine mammals of the suborder Caniformia. J. Archaeol. Sci. Rep. 15, 393-400. doi: 10.1016/J. JASREP.2017.09.007

Corkeron, P. J., and Connor, R. C. (1999). Why do baleen whales migrate. Mar. Mamm. Sci. 15, 1228-1245. doi: 10.1111/j.1748-7692.1999.tb00887.x

Corkeron, P. J., Rolland, R. M., Hunt, K. E., and Kraus, S. D. (2017). A right whale pootree: classification trees of faecal hormones identify reproductive states in North Atlantic right whales (Eubalaena glacialis). Conserv. Physiol. 5:cox006. doi: 10.1093/conphys/cox006

Costanzo, S. D., O’Donohue, M. J., Dennison, W. C., Loneragan, N. R., and Thomas, M. (2001). A new approach for detecting and mapping sewage impacts. Mar. Pollut. Bull. 42, 149-156. doi: 10.1016/S0025-326X(00)00125-9
Covino, K. M., Jawor, J. M., Kelly, J. F., and Moore, F. R. (2017). Overlapping life-history stages in migrating songbirds: variation in circulating testosterone and testosterone production capacity. J. Ornithol. 158, 203-212. doi: 10.1007/ s10336-016-1385-1388

Crocker, D. E., Ortiz, R. M., Houser, D. S., Webb, P. M., and Costa, D. P. (2012). Hormone and metabolite changes associated with extended breeding fasts in male northern elephant seals (Mirounga angustirostris). Comp. Biochem. Physiol. A Mol. Integr. Physiol. 161, 388-394. doi: 10.1016/j.cbpa.2011.12.013

Das, K., Siebert, U., Fontaine, M., Jauniaux, T., Holsbeek, L., and Bouquegneau, J. M. (2004). Ecological and pathological factors related to trace metal concentrations in harbour porpoises Phocoena phocoena from the North Sea and adjacent areas. Mar. Ecol. Prog. Ser. 281, 283-295. doi: 10.3354/meps281283

deHart, P. A. P., and Picco, C. M. (2015). Stable oxygen and hydrogen isotope analyses of bowhead whale baleen as biochemical recorders of migration and arctic environmental change. Polar Sci. 9, 235-248. doi: 10.1016/J.POLAR.2015. 03.002

DeNiro, M. J., and Epstein, S. (1978). Influence of diet on the distribution of carbon isotopes in animals. Geochim. Cosmochim. Acta 42, 495-506. doi: 10.1016/00 16-7037(78)90199-0

DeNiro, M. J., and Epstein, S. (1981). Influence of diet on the distribution of nitrogen isotopes in animals. Geochim. Cosmochim. Acta 45, 341-351. doi: 10.1016/0016-7037(81)90244-1

Deroos, C. C., and Bern, H. A. (1961). The corticoids of the adrenal of the California sea lion (Zalophus californianus). Gen. Comp. Endocrinol. 1, 275-285. doi: 10.1016/0016-6480(61)90035-1

Dorresteijn, I., Kitaysky, A. S., Barger, C. P., Benowitz-Fredericks, Z., Byrd, G., Shultz, M. T., et al. (2012). Climate affects food availability to planktivorous least auklets Aethia pusilla through physical processes in the southeastern Bering Sea. Mar. Ecol. Prog. Ser. 454, 207-220. doi: 10.3354/meps09372

du Dot, T., Rosen, D. A. S., Richmond, J., Kitaysky, A. S., Zinn, S., and Trites, A. (2009). Changes in glucocorticoids, IGF-I and thyroid hormones as indicators of nutritional stress and subsequent refeeding in Steller sea lions (Eumetopias jubatus). Comp. Biochem. Physiol. A 152, 524-534. doi: 10.1016/j.cbpa.2008. 12.010

Elia, M., Stubbs, R. J., and Henry, C. J. K. (1999). Differences in fat, carbohydrate, and protein metabolism between lean and obese subjects undergoing total starvation. Obes. Res. 7, 597-604. doi: 10.1002/j.1550-8528.1999.tb00720.x

Fairhurst, G. D., Bond, A. L., Hobson, K. A., and Ronconi, R. A. (2015). Featherbased measures of stable isotopes and corticosterone reveal a relationship between trophic position and physiology in a pelagic seabird over a 153-year period. Ibis 157, 273-283. doi: 10.1111/ibi.12232

Fernández, R., García-Tiscar, S., Begoña Santos, M., López, A., Martínez-Cedeira, J. A., Newton, J., et al. (2011). Stable isotope analysis in two sympatric populations of bottlenose dolphins Tursiops truncatus: evidence of resource partitioning? Mar. Biol. 158, 1043-1055. doi: 10.1371/journal.pone.0181526

Fleming, A. H., Clark, C. T., Calambokidis, J., and Barlow, J. (2016). Humpback whale diets respond to variance in ocean climate and ecosystem conditions in the California current. Glob. Chang. Biol. 22, 1214-1224. doi: 10.1111/gcb.13171

Fry, B. (2006). Stable Isotope Ecology. New York, NY: Springer New York. doi: 10.1007/0-387-33745-8

Gardiner, K. J., Boyd, I. L., Follett, B. K., Racey, P. A., and Reijnders, P. J. H. (1999). Changes in pituitary, ovarian, and testicular activity in harbour seals (Phoca vitulina) in relation to season and sexual maturity. Can. J. Zool. 77, 211-221. doi: 10.1139/z98-211

Gardiner, K. J., Boyd, I. L., Racey, P. A., Reijnders, P. J. H., and Thompson, P. M. (1996). Plasma progesterone concentrations measured using an enzymelinked immunosorbent assay useful for diagnosing pregnancy in harbor seals (Phoca vitulina). Mar. Mamm. Sci. 12, 265-273. doi: 10.1111/j.1748-7692.1996. tb00575.x

Germain, L. R., Koch, P. L., Harvey, J., and McCarthy, M. D. (2013). Nitrogen isotope fractionation in amino acids from harbor seals: implications for compound-specific trophic position calculations. Mar. Ecol. Prog. Ser. 482, 265-277. doi: 10.3354/meps10257

Giménez, J., Gómez-Campos, E., Borrell, A., Cardona, L., and Aguilar, A. (2013). Isotopic evidence of limited exchange between Mediterranean and eastern North Atlantic fin whales. Rapid Commun. Mass Spectrom. 27, 1801-1806. doi: $10.1002 / \mathrm{rcm} .6633$ 
Gomez-Campos, E., Borrell, A., and Aguilar, A. (2011). Nitrogen and carbon stable isotopes do not reflect nutritional condition in the striped dolphin. Rapid Commun. Mass Spectrom. 25, 1343-1347. doi: 10.1002/rcm.4999

Goutte, A., Bustamante, P., Barbraud, C., Delord, K., Weimerskirch, H., and Chastel, O. (2014). Demographic responses to mercury exposure in two closely related Antarctic top predators. Ecology 95, 1075-1086. doi: 10.1890/13-1229.1

Gregory, L. F., Gross, T. S., Bolten, A. B., Bjorndal, K. A., and Guillette, L. J. (1996). Plasma corticosterone concentrations associated with acute captivity stress in wild loggerhead sea turtles (Caretta caretta). Gen. Comp. Endocrinol. 104, 312-320. doi: 10.1006/gcen.1996.0176

Greig, D. J., Mashburn, K., Rutishauser, M., Gulland, F., Williams, T. M., and Atkinson, S. (2007). Seasonal changes in circulating progesterone and estrogen concentrations in the California sea lion (Zalophus californianus). J. Mamm. 88, 67-72. doi: 10.1644/06-MAMM-A-060R2.1

Gross, T. S., Crain, D. A., Bjorndal, K. A., Bolten, A. B., and Carthy, R. R. (1995). Identification of sex in hatchling loggerhead turtles (Caretta caretta) by analysis of steroid concentrations in chorioallantoic/amniotic fluid. Gen. Comp. Endocrinol. 99, 204-210. doi: 10.1006/gcen.1995.1103

Hazen, E. L., Friedlaender, A. S., Thompson, M. A., Ware, C. R., Weinrich, M. T., Halpin, P. N., et al. (2009). Fine-scale prey aggregations and foraging ecology of humpback whales Megaptera novaeangliae. Mar. Ecol. Prog. Ser. 395, 75-89. doi: $10.3354 /$ meps 08108

Hobson, K. A. (1999). Tracing origins and migration of wildlife using stable isotopes: a review. Oecologia 120, 314-326. doi: 10.1007/s004420050865

Hobson, K. A., Alisauskas, R. T., and Clark, R. G. (1993). Stable-nitrogen isotope enrichment in avian tissues due to fasting and nutritional stress: implications for isotopic analysis of diet. Condor 95, 388-394. doi: 10.2307/1369361

Hobson, K. A., and Welch, H. E. (1992). Determination of trophic relationships within a high Arctic marine food web using $\delta 13 \mathrm{C}$ and $\delta 15 \mathrm{~N}$ analysis. Mar. Ecol. Prog. Ser. 84, 9-18. doi: 10.3354/meps084009

Hochachka, P. W., Liggins, G. C., Guyton, G. P., Schneider, R. C., Stanek, K. S., Hurford, W. E., et al. (1995). Hormonal regulatory adjustments during voluntary diving in Weddell seals. Comp. Biochem. Physiol. B Biochem. Mol. Biol. 112, 361-375. doi: 10.1016/0305-0491(96)85239-4

Hopkins, J. B. III, Ferguson, J., Tyers, D., and Kurle, C. M. (2017). Selecting the best stable isotope mixing model to estimate grizzly bear diets in the greater yellowstone ecosystem. PLoS One 19:e0174903. doi: 10.1371/journal. pone. 0174903

Hopkins, J. B. III, and Kurle, C. M. (2016). Meauring the realized niches of animals using stable isotopes: from rats to bears. Methods Ecol. Evol. 7, 210-221. doi: 10.1111/2041-210X.12446

Horton, H. R., and Moran, L. A. (1996). Principles of Biochemistry. London: Worth Publishers.

Houser, D. S., Yeates, L. C., and Crocker, D. E. (2011). Cold stress induces an adrenocortical response in bottlenose dolphins (Tursiops truncatus). J. Zoo Wildl. Med. 42, 565-571. doi: 10.1638/2010-0121.1

Howard, J., Babij, E., Griffis, R., Helmuth, B., Himes-Cornell, A., Niemier, P., et al. (2013). Oceans and marine resources in a changing climate. Oceanogr. Mar. Biol. 51, 71-192.

Hückstädt, L. A., McCarthy, M. D., Koch, P. L., and Costa, D. P. (2017). What difference does a century make? Shifts in the ecosystem structure of the Ross Sea, Antarctica, as evidenced from a sentinel species, the Weddell seal. Proc. Biol. Sci. 284:20170927. doi: 10.1098/rspb.2017.0927

Hunt, K. E., Innis, C. J., Merigo, C., and Rolland, R. M. (2016a). Endocrine responses to diverse stressors of capture, entanglement and stranding in leatherback turtles (Dermochelys coriacea). Conserv. Physiol. 4:cow022. doi: 10.1093/conphys/cow022

Hunt, K. E., Lysiak, N. S., Moore, M. J., and Rolland, R. M. (2016b). Longitudinal progesterone profiles in baleen from female North Atlantic right whales (Eubalaena glacialis) match known calving history. Conserv. Physiol. 4:cow014. doi: 10.1093/conphys/cow014

Hunt, K. E., Rolland, R. M., Kraus, S. D., and Wasser, S. K. (2006). Analysis of fecal glucocorticoids in the North Atlantic right whale (Eubalaena glacialis). Gen. Comp. Endocrinol. 148, 260-272. doi: 10.1016/j.ygcen.2006.03.012

Hunt, K. E., Stimmelmayr, R., George, C., Hanns, C., Suydam, R., Brower, H., et al. (2014). Baleen hormones: a novel tool for retrospective assessment of stress and reproduction in bowhead whales (Balaena mysticetus). Conserv. Physiol. 2:cou030. doi: 10.1093/conphys/cou030
Jackson, A. L., Inger, R., Parnell, A. C., and Bearhop, S. (2011). Comparing isotopic niche widths among and within communities: SIBER - stable isotope bayesian ellipses in R. J. Anim. Ecol. 80, 595-602. doi: 10.1111/j.1365-2656.2011.01806.x

Jensen, M. P., Allen, C. D., Eguchi, T., Bell, I., LaCasella, E., Hilton, W. A., et al. (2018). Environmental warming and feminization of one of the largest sea turtle populations in the world. Curr. Biol. 28, 154-159. doi: 10.1016/j.cub.2017. 11.057

Kakizoe, Y., Fujiwara, M., Akune, Y., Kanou, Y., Saito, T., and Uchida, I. (2010). Cyclical changes of plasma sex steroids in captive breeding loggerhead turtles (Caretta caretta). J. Zoo Wildl. Med. 41, 643-648. doi: 10.1638/2009-0254.1

Kellar, N. M., Catelani, K. N., Robbins, M. N., Trego, M. L., Allen, C. D., Danil, K., et al. (2015). Blubber cortisol: a potential tool for assessing stress response in free-ranging dolphins without effects due to sampling. PLoS One 10:e0115257. doi: 10.1371 /journal.pone. 0115257

Kellar, N. M., Speakman, T., Smith, C., Lane, S., Balmer, B., Trego, M. L., et al. (2017). Low reproductive success rates of common bottlenose dolphins (Tursiops truncatus) in the northern gulf of mexico following the deepwater horizon disaster (2010-2015). Endanger. Species Res. 33, 143-158. doi: 10.3354/ esr00775

Kellar, N. M., Trego, M. L., Chivers, S. J., and Archer, F. I. (2013). Pregnancy patterns of pantropical spotted dolphins (Stenella attenuata) in the eastern tropical Pacific determined from hormonal analysis of blubber biopsies and correlations with the purse-seine tuna fishery. Mar. Biol. 160, 3113-3124. doi: 10.1007/s00227-013-2299-2290

Kellar, N. M., Trego, M. L., Chivers, S. J., Archer, F. I., and Perryman, W. L. (2014). From progesterone in biopsies to estimates of pregnancy rates: large scale reproductive patterns of two sympatric species of common dolphin, Delphinus spp. off California, USA and Baja, Mexico. Bull. South. Calif. Acad. Sci. 113, 58-80. doi: 10.3160/0038-3872-113.2.58

Kellar, N. M., Trego, M. L., Marks, C. I., Chivers, S. J., Danil, K., and Archer, F. I. (2009). Blubber testosterone: a potential marker of male reproductive status in short-beaked common dolphins. Mar. Mamm. Sci. 25, 507-522. doi: 10.1111/j.1748-7692.2009.00291.x

Kellar, N. M., Trego, M. L., Marks, C. I., and Dizon, A. E. (2006). Determining pregnancy from blubber in three species of delphinids. Mar. Mamm. Sci. 22, 1-16. doi: 10.1111/j.1748-7692.2006.00001.x

Kiszka, J., Oremus, M., Richard, P., Poole, M., and Ridoux, V. (2010). The use of stable isotope analyses from skin biopsy samples to assess trophic relationships of sympatric delphinids off Moorea (French Polynesia). J. Exp. Mar. Bio. Ecol. 395, 48-54. doi: 10.1016/j.jembe.2010.08.010

Kouwenberg, A.-L., Mark Hipfner, J., McKay, D. W., and Storey, A. E. (2013). Corticosterone and stable isotopes in feathers predict egg size in Atlantic Puffins Fratercula arctica. Ibis 155, 413-418. doi: 10.1111/ibi.12030

Kurle, C. M. (2009). Interpreting temporal variation in omnivore foraging ecology via stable isotope modelling. Funct. Ecol. 23, 733-744. doi: 10.1111/j.1365-2435. 2009.01553.x

Kurle, C. M., and Gudmundson, C. J. (2007). Regional differences in foraging of young-of-the-year Steller sea lions Eumetopias jubatus in Alaska: stable carbon and nitrogen isotope ratios in blood. Mar. Ecol. Prog. Ser. 342, 303-310. doi: $10.3354 /$ meps342303

Kurle, C. M., Koch, P. L., Tershy, B. R., and Croll, D. A. (2014). The effects of sex, tissue type, and dietary components on stable isotope discrimination factors $\left(\Delta^{13} \mathrm{C}\right.$ and $\left.\Delta^{15} \mathrm{~N}\right)$ in mammalian omnivores. Isotopes Environ. Health Stud. 50, 307-321. doi: 10.1080/10256016.2014.908872

Kurle, C. M., and McWhorter, J. K. (2017). Spatial and temporal variability within marine isoscapes?: implications for interpreting stable isotope data from marine systems. Mar. Ecol. Prog. Ser. 568, 31-45. doi: 10.3354/meps 12045

Kurle, C. M., Sinclair, E. H., Edwards, A. E., and Gudmundson, C. J. (2011). Temporal and spatial variation in the $\delta 15 \mathrm{~N}$ and $\delta 13 \mathrm{C}$ values of fish and squid from Alaskan waters. Mar. Biol. 158, 2389-2404. doi: 10.1007/s0022 7-011-1741-1744

Lafferty, D. J. R., Laudenslager, M. L., Mowat, G., Heard, D., and Belant, J. L. (2015). Sex, diet, and the social environment: factors influencing hair cortisol concentration in free-ranging black bears $(<\mathrm{i}>$ Ursus americanus $<\mathrm{i} />$ ). PLoS One 10:e0141489. doi: 10.1371/journal.pone.0141489

Larsen, T., Taylor, D. L., Leigh, M. B., and O’Brien, D. M. (2009). Stable isotope fingerprinting: a novel method for identifying plant, fungal, or bacterial origins of amino acids. Ecology 90, 3526-3535. doi: 10.1890/08-1695.1 
Larsen, T., Ventura, M., Andersen, N., O’Brien, D. M., Piatkowski, U., and McCarthy, M. D. (2013). Tracing carbon sources through aquatic and terrestrial food webs using amino acid stable isotope fingerprinting. PLoS One 8:e73441. doi: 10.1371/journal.pone.0073441

Layman, C. A., Arrington, D. A., Montana, C. G., and Post, D. M. (2007). Can stable isotope ratios provide for community wide measures of trophic structure? Ecology 88, 42-48.

Lemons, G., Lewison, R., Komoroske, L., Gaos, A., Chun-Ta, L., Dutton, P., et al. (2011). Trophic ecology of green sea turtles in a highly urbanized bay: insights from stable isotopes and mixing models. J. Exp. Mar. Bio. Ecol. 405, 25-32. doi: 10.1016/j.jembe.2011.05.012

Licht, P., Owens, D. W., Cliffton, K., and Penaflores, C. (1982). Changes in LH and progesterone associated with the nesting cycle and ovulation in the olive ridley sea turtle, Lepidochelys olivacea. Gen. Comp. Endocrinol. 48, 247-253. doi: 10.1016/0016-6480(82)90023-5

Liggins, G. C., France, J. T., Knox, B. S., and Zapol, W. M. (1979). High corticosteroid levels in plasma of adult and foetal Weddell seals (Leptonychotes weddelli). Acta Endocrinol. 90, 718-726. doi: 10.1530/acta.0.0900718

Lohuis, T. D., Harlow, H. J., and Beck, T. D. I. (2007). Hibernating black bears (Ursus americanus) experience skeletal muscle protein balance during winter anorexia. Comp. Biochem. Physiol. B 147, 20-28. doi: 10.1016/j.cbpb.2006.12.020

Lorrain, A., Graham, B. S., Popp, B. N., Allain, V., Olson, R. J., Hunt, B. P. V., et al. (2014). Nitrogen isotopic baselines and implications for estimating foraging habitat and trophic position of yellowfin tuna in the Indian and Pacific Oceans. Deep Sea Res. Part II Top. Stud. Oceanogr. 113, 188-198. doi: 10.1016/j.dsr2. 2014.02.003

Lowther, A. D., and Goldsworthy, S. D. (2011). Detecting alternate foraging ecotypes in Australian sea lion (Neophoca cinerea) colonies using stable isotope analysis. Mar. Mamm. Sci. 27, 567-586. doi: 10.1111/j.1748-7692.2010.00425.x

MacAvoy, S. E., Cortese, N., Cybulski, J., Hohn, A. A., and Macko, S. A. (2017). Sources of stable isotope variation among stranded Western Atlantic dolphins (Tursiops truncatus) in North Carolina. Mar. Mamm. Sci. 33, 1224-1234. doi: $10.1111 / \mathrm{mms} .12425$

Macklin, S. A., Hunt, G. L., and Overland, J. E. (2002). Collaborative research on the pelagic ecosystem of the southeastern Bering Sea shelf. Deep Sea Res. Part II Top. Stud. Oceanogr. 49, 5813-5819. doi: 10.1016/S0967-0645(02)00320-X

Malvin, R. L., Ridgway, S. H., and Cornell, L. (1978). Renin and aldosterone levels in dolphins and sea lions. Proc. Soc. Exp. Biol. Med. 157, 665-668. doi: 10.3181/00379727-157-40117

Mansour, A. A. H., McKay, D. W., Lien, J., Orr, J. C., Banoub, J. H., Oien, N., et al. (2002). Determination of pregnancy status from blubber samples in minke whales (Balaenoptera acutorostrata). Mar. Mamm. Sci. 18, 112-120. doi: 10.1111/j.1748-7692.2002.tb01022.x

Mashburn, K., and Atkinson, S. (2004). Evaluation of adrenal function in serum and feces of Steller sea lions (Eumetopias jubatus): influences of molt, gender, sample storage, and age on glucocorticoid metabolism. Gen. Comp. Endocrinol. 136, 371-381. doi: 10.1016/j.ygcen.2004.01.016

McKenzie, J., Parry, L. J., Page, B., and Goldsworthy, S. D. (2005). Estimation of pregnancy rates and reproductive failure in New Zealand fur seals (Arctocephalus forsteri). J. Mamm. 86, 1237-1246. doi: 10.1644/0 5-MAMM-A-085R.1

McMahon, K. W., Hamady, L. L., and Thorrold, S. R. (2013). A review of ecogeochemistry approaches to estimating movements of marine animals. Limnol. Oceanogr. 58, 697-714. doi: 10.4319/lo.2013.58.2.0697

McMahon, K. W., and McCarthy, M. D. (2016). Embracing variability in amino acid $\delta 15 \mathrm{~N}$ fractionation: mechanisms, implications, and applications for trophic ecology. Ecosphere 7:e01511. doi: 10.1002/ecs2.1511

McMahon, K. W., McCarthy, M. D., Sherwood, O. A., Larsen, T., and Guilderson, T. P. (2015a). Millennial-scale plankton regime shifts in the subtropical North Pacific Ocean. Science 350, 1530-1533. doi: 10.1126/science.aaa9942

McMahon, K. W., Polito, M. J., Abel, S., McCarthy, M. D., and Thorrold, S. R. (2015b). Carbon and nitrogen isotope fractionation of amino acids in an avian marine predator, the gentoo penguin (Pygoscelis papua). Ecol. Evol. 5, 1278-1290. doi: 10.1002/ece3.1437

McMahon, K. W., Thorrold, S. R., Elsdon, T. S., and McCarthy, M. D. (2015c). Trophic discrimination of nitrogen stable isotopes in amino acids varies with diet quality in a marine fish. Limnol. Oceanogr. 60, 1076-1087. doi: 10.1002/ lno. 10081

Melmed, S., Polonsky, K. S., Larsen, P. R., and Kronenberg, H. (2016). Williams Textbook of Endocrinology. Philadelphia, PA: Elsevier.

Moon, D. Y., Mackenzie, D. S., and Owens, D. W. (1998). Serum thyroid hormone levels in wild and captive sea turtles. Korean J. Biol. Sci. 2, 177-181. doi: 10.1080/ 12265071.1998.9647404

Moon, D. Y., Owens, D. W., and MacKenzie, D. S. (1999). The effects of fasting and increased feeding on plasma thyroid hormones, glucose, and total protein in sea turtles. Zool. Sci. 16, 579-586. doi: 10.2108/zsj.16.579

National Academies of Sciences, Engineering, and Medicine (2017). Approaches to Understanding the Cumulative Effects of Stressors on Marine Mammals. Washington, DC: National Academies Press.

Newsome, S. D., Clementz, M. T., and Koch, P. L. (2010). Using stable isotope biogeochemistry to study marine mammal ecology. Mar. Mamm. Sci. 26, 509-572. doi: 10.1111/j.1748-7692.2009.00354.x

Newsome, S. D., Etnier, M. A., Kurle, C. M., Waldbauer, J. R., Chamberlain, C. P., and Koch, P. L. (2007a). Historic decline in primary productivity in western Gulf of Alaska and eastern Bering Sea: isotopic analysis of northern fur seal teeth. Mar. Ecol. Prog. Ser. 332, 211-224. doi: 10.3354/meps332211

Newsome, S. D., Rio, Martinez del, C., Bearhop, S., and Phillips, D. L. (2007b). A niche for isotope ecology. Front. Ecol. Environ. 5, 429-436. doi: 10.1890/ 060150.01

Newsome, S. D., Yeakel, J. D., Wheatley, P. V., and Tinker, M. T. (2012). Tools for quantifying isotopic niche space and dietary variation at the individual and population level. J. Mamm. 93, 329-341. doi: 10.1644/11-MAMM-S-187.1

Nielsen, J. M., Popp, B. N., and Winder, M. (2015). Meta-analysis of amino acid stable nitrogen isotope ratios for estimating trophic position in marine organisms. Oecologia 178, 631-642. doi: 10.1007/s00442-015-3305-3307

Nielson, J. M., and Winder, M. (2015). Seasonal dynamics of zooplankton resource use revealed by carbon amino acid stable isotope values. Mar. Ecol. Prog. Ser. 531, 143-154. doi: 10.3354/meps11319

O'Connell, T. C. (2017). "Trophic" and "source" amino acids in trophic estimation: a likely metabolic explanation. Oecologia 184, 317-326. doi: 10.1007/s00442017-3881-3889

Ohman, M. D., Rau, G. H., and Hull, P. M. (2012). Multi-decadal variations in stable N isotopes of California current zooplankton. Deep Sea Res. Part I 60, 46-55. doi: 10.1016/j.dsr.2011.11.003

Ortiz, R., Patterson, R., Wade, C., and Byers, F. (2000). Effects of acute fresh water exposure on water flux rates and osmotic responses in Kemp's ridley sea turtles (Lepidochelys kempi). Comp. Biochem. Physiol. A Mol. Integr. Physiol. 127, 81-87. doi: 10.1016/S1095-6433(00)00240-3

Oskam, I. C., Ropstad, E., Dahl, E., Lie, E., Derocher, A. E., Wiig, O., et al. (2003). Organochlorines affect the major androgenic hormone, testosterone, in male polar bears (Ursus maritimus) at Svalbard. J. Toxicol. Environ. Heal. A 66, 2119-2139. doi: 10.1080/15287390390211342

Owens, D. W. (1999). "Reproductive cycles and endocrinology," in Research and Management Techniques for the Conservation of Sea Turtles, eds K. L. Eckert, K. A. Bjorndal, F. A. Abreu-Grobois, and M. Donnelly (Washington, DC: IUCN/SSC Marine Turtle Specialist Group Publication No. 4), 119-123.

Palme, R., Rettenbacher, S., Touma, C., El-Bahr, S. M., and Mostl, E. (2005). "Stress hormones in mammals and birds - comparative aspects regarding metabolism, excretion, and noninvasive measurement in fecal samples," in Trends in Comparative Endocrinology and Neurobiology, eds H. Vaudry, E. Roubos, L. Schoofs, G. Fiik, and D. Larhammar (New York, NY: New York Academy of Sciences), 162-171. doi: 10.1196/annals. 1327.021

Perez, S., Garcia-Lopez, A., De Stephanis, R., Giménez, J., Garcia-Tiscar, S., Verborgh, P., et al. (2011). Use of blubber levels of progesterone to determine pregnancy in free-ranging live cetaceans. Mar. Biol. 158, 1677-1680. doi: 10. 1007/s00227-011-1676-1679

Peterson, B. J., and Fry, B. (1987). Stable isotopes in ecosystem studies. Annu. Rev. Ecol. Syst. 18, 293-320. doi: 10.1146/annurev.es.18.110187.001453

Pietraszek, J., and Atkinson, S. (1994). Concentrations of estrone sulfate and progesterone in plasma and saliva, vaginal cytology, and bioelectric impedance during the estrous cycle of the Hawaiian monk seal (Monachus schaunslandi). Mar. Mamm. Sci. 10, 430-441. doi: 10.1111/j.1748-7692.1994.tb00499.x 
Pineda, M. H., Martin, P. A., Crump, M. H., Dooley, M. P., Pineda, M. H., and Dooley, M. P. (2003). McDonald's Veterinary Endocrinology and Reproduction, 5th Edn. Ames, IA: Blackwell Publishing.

Polischuk, S. C., Hobson, K. A., and Ramsay, M. A. (2001). Use of stable-carbon and -nitrogen isotopes to assess weaning and fasting in female polar bears and their cubs. Can. J. Zool. 79, 499-511. doi: 10.1139/z01-007

Pomerleau, C., Heide-Jørgensen, M. P., Ferguson, S. H., Stern, H. L., Høyer, J. L., and Stern, G. A. (2017). Reconstructing variability in West Greenland ocean biogeochemistry and bowhead whale (Balaena mysticetus) food web structure using amino acid isotope ratios. Polar Biol. 40, 2225-2238. doi: 10.1007/s003 00-017-2136-x

Popp, B. N., Graham, B. S., Olson, R. J., Hannides, C. S., Lott, M. J., Lopez-Ibarra, G. A., et al. (2007). "Insight into the trophic ecology of yellowfin tuna, Thunnus albacares from compound-specific nitrogen isotope analysis of proteinaceous amino acids," in Stable Isotopes as Indicators of Ecological Change, eds T. Dawson and R. Siegwolf (New York, NY: Elsevier), 173-190.

Popp, B. N., Laws, E. A., Bidigare, R. R., Dore, J. E., Hanson, K. L., and Wakeham, S. G. (1998). Effect of phytoplankton cell geometry on carbon isotopic fractionation. Geochim. Cosmochim. Acta 62, 69-77. doi: 10.1016/ S0016-7037(97)00333-5

Post, D. M. (2002). Using stable isotopes to estimate trophic position: models, methods, and assumptions. Ecology 83, 703-718. doi: 10.1890/0012-9658(2002) 083[0703:USITET]2.0.CO;2

Rau, G. H., Ohman, M. D., and Pierrot-Bults, A. (2003). Linking nitrogen dynamics to climate variability off central California: a 51 year record based on $15 \mathrm{~N} / 14 \mathrm{~N}$ in CalCOFI zooplankton. Deep Sea Res. Part II Top. Stud. Oceanogr. 50, 2431-2447. doi: 10.1016/S0967-0645(03)00128-120

Rau, G. H., Sweeney, R. E., and Kaplan, I. R. (1982). Plankton 13C: 12C ratio changes with latitude: differences between northern and southern oceans. Deep Sea Res. Part A. Oceanogr. Res. Pap. 29, 1035-1039. doi: 10.1016/0198-0149(82) 90026-90027

Read, A. J. (2008). The looming crisis: interactions between marine mammals and fisheries. J. Mamm. 89, 541-548. doi: 10.1644/07-MAMM-S-315R1.1

Riofrío-Lazo, M., and Aurioles-Gamboa, D. (2013). Timing of isotopic integration in marine mammal skull: comparative study between calcified tissues. Rapid Commun. Mass Spectrom. 27, 1076-1082. doi: 10.1002/rcm.6556

Robards, M. D., Burns, J. J., Meek, C. L., and Watson, A. (2009). Limitations of an optimum sustainable population or potential biological removal approach for conserving marine mammals: pacific walrus case study. J. Environ. Manage. 91, 57-66. doi: 10.1016/j.jenvman.2009.08.016

Robeck, T. R., Atkinson, S., and Brook, F. (2001). "Reproduction," in CRC Handbook of Marine Mammal Medicine: Health, Disease, and Rehabilitation, eds L. Dierauf and F. M. D. Gulland (Boca Raton, FL: CRC press), 193-236. doi: 10.1201/9781420041637.ch11

Robeck, T. R., and Monfort, S. L. (2006). Characterization of male killer whale (Orcinus orca) sexual maturation and reproductive seasonality. Theriogenology 66, 242-250. doi: 10.1016/j.theriogenology.2005.11.007

Rolland, R. M., Hunt, K. E., Kraus, S. D., and Wasser, S. K. (2005). Assessing reproductive status of right whales (Eubalaena glacialis) using fecal hormone metabolites. Gen. Comp. Endocrinol. 142, 308-317. doi: 10.1016/j.ygcen.2005. 02.002

Rolland, R. M., Parks, S. E., Hunt, K. E., Castellote, M., Corkeron, P. J., Nowacek, D. P., et al. (2012). Evidence that ship noise increases stress in right whales. Proc. R. Soc. Lond. B Biol. Sci. 279, 2363-2368. doi: 10.1098/rspb.2011. 2429

Rosen, D. A. S., and Kumagai, S. (2008). Hormone changes indicate that winter is a critical period for food shortages in Steller sea lions. J. Comp. Physiol. B 178, 573-583. doi: 10.1007/s00360-007-0247-3

Rosen, D. A. S., and Trites, A. (2002). Changes in metabolism in response to fasting and food restriction in the Steller sea lion (Eumetopias jubatus). Comp. Biochem. Physiol. B Biochem. Mol. Biol. 132, 389-399. doi: 10.1016/S10 96-4959(02)00048-9

Rossman, S., Ostrom, P. H., Gordon, F., and Zipkin, E. F. (2016). Beyond carbon and nitrogen: guidelines for estimating three-dimensional isotopic niche space. Ecol. Evol. 6, 2405-2413. doi: 10.1002/ece3.2013

Ruiz-Cooley, R. I., and Gerrodette, T. (2012). Tracking large-scale latitudinal patterns of $\mathrm{d} 13 \mathrm{C}$ and $\mathrm{d} 15 \mathrm{~N}$ along the eastern Pacific using epi-mesopelagic squid as indicators. Ecosphere 3:63. doi: 10.1890/ES12-00094.1
Ruiz-Cooley, R. I., Gerrodette, T., Fiedler, P. C., Chivers, S. J., Danil, K., and Ballance, L. T. (2017). Temporal variation in pelagic food chain length in response to environmental change. Sci. Adv. 3:e1701140. doi: 10.1126/sciadv. 1701140

Ruiz-Cooley, R. I., Koch, P. L., Fiedler, P. C., and McCarthy, M. D. (2014). Carbon and nitrogen isotopes from top predator amino acids reveal rapidly shifting ocean biochemistry in the outer California current. PLoS One 9:e110355. doi: 10.1371/journal.pone.0110355

Ryan, C., McHugh, B., Trueman, C. N., Sabin, R., Deaville, R., Harrod, C., et al. (2013). Stable isotope analysis of baleen reveals resource partitioning among sympatric rorquals and population structure in fin whales. Mar. Ecol. Prog. Ser. 479, 251-261. doi: 10.3354/meps10231

Santora, J. A., Sydeman, W. J., Schroeder, I. D., Wells, B. K., and Field, J. C. (2011). Mesoscale structure and oceanographic determinants of krill hotspots in the California current: implications for trophic transfer and conservation. Prog. Oceanogr. 91, 397-409. doi: 10.1016/j.pocean.2011.04.002

Schell, D. M. (2000). Declining carrying capacity in the Bering Sea: isotopic evidence from whale baleen. Limnol. Oceanogr. 45, 459-462. doi: 10.4319/lo. 2000.45.2.0459

Schwacke, L., Smith, C., Townsend, F. I., Wells, R. S., Hart, L. B., Balmer, B., et al. (2014). Health of common bottlenose dolphins (Tursiops truncatus) in barataria bay, louisiana, following the deepwater horizon oil spill. Environ. Sci. Technol. 48, 93-103. doi: 10.1021/es403610f

Sheriff, M. J., Dantzer, B., Delehanty, B., Palme, R., and Boonstra, R. (2011). Measuring stress in wildlife: techniques for quantifying glucocorticoids. Oecologia 166, 869-887. doi: 10.1007/s00442-011-1943-y

Sherwood, O. A., Lehmann, M. F., Schubert, C. J., Scott, D. B., and McCarthy, M. D. (2011). Nutrient regime shift in the western North Atlantic indicated by compound-specific $15 \mathrm{~N}$ of deep-sea gorgonian corals. Proc. Natl. Acad. Sci. 108, 1011-1015. doi: 10.1073/pnas.1004904108

Snover, M. L., Hohn, A. A., Goshe, L. R., and Balazs, G. H. (2011). Validation of annual skeletal marks in green sea turtles Chelonia mydas using tetracycline labeling. Aquat. Biol. 12, 197-204. doi: 10.3354/ab00337

Somes, C. J., Schmittner, A., Galbraith, E. D., Lehmann, M. F., Altabet, M. A., Montoya, J. P., et al. (2010). Simulating the global distribution of nitrogen isotopes in the ocean. Global Biogeochem. Cycles 24:GB4019. doi: 10.1029/ 2009GB003767

St. Aubin, D. J. (2001). “Endocrinology," in CRC Handbook of Marine Mammal Medicine, eds L. A. Dierauf and F. Gulland (London: Taylor \& Francis Inc), 253-269. doi: 10.1201/9781420041637.ch13

St. Aubin, D. J., and Dierauf, L. A. (2001). "Stress and marine mammals," in CRC Handbook of Marine Mammal Medicine, eds L. A. Dierauf and F. Gulland (Boca Raton, FL: CRC Press), 253-269. doi: 10.1201/9781420041637.ch13

St. Aubin, D. J., Forney, K. A., Chivers, S. J., Scott, M. D., Danil, K., Romano, T. A., et al. (2013). Hematological, serum, and plasma chemical constituents in pantropical spotted dolphins (Stenella attenuata) following chase, encirclement, and tagging. Mar. Mamm. Sci. 29, 14-35. doi: 10.1111/j.1748-7692.2011.00536.x

St. Aubin, D. J., and Geraci, J. R. (1988). Capture and handling stress suppresses circulating levels of thyroxine (T4) and triiodothyronine (T3) in beluga whales Delphinapterus leucas. Physiol. Zool. 61, 170-175. doi: 10.1086/physzool.61.2. 30156148

St. Aubin, D. J., and Geraci, J. R. (1989). Adaptive changes in hematologic and plasma chemical constituents in captive beluga whales, Delphinapterus leucas. Can. J. Fish. Aquat. Sci. 46, 796-803. doi: 10.1139/f89-099

St. Aubin, D. J., Ridgway, S. H., Wells, R. S., and Rhinehart, H. (1996). Dolphin thyroid and adrenal hormones: circulating levels in wild and semidomesticated Tursiops truncatus, and influence of sex, age, and season. Mar. Mamm. Sci 12, 1-13. doi: 10.1111/j.1748-7692.1996.tb00301.x

Stabeno, P. J., Kachel, N. B., Moore, S. E., Napp, J. M., Sigler, M., Yamaguchi, A., et al. (2012). Comparison of warm and cold years on the southeastern Bering Sea shelf and some implications for the ecosystem. Deep Sea Res. Part II Top. Stud. Oceanogr. 6, 31-45. doi: 10.1016/j.dsr2.2012.02.020

Stock, B. C., Jackson, A. L., Ward, E. J., Parnell, A. C., Phillips, D. L., and Semmens, B. X. (2018). Analyzing mixing systems using a new generation of Bayesian tracer mixing models. PeerJ 6:e5096. doi: 10.7717/peerj.5096

Stock, C. A., Dunne, J. P., and John, J. G. (2014). Drivers of trophic amplification of ocean productivity trends in a changing climate. Biogeosciences 11, 7125-7135. doi: 10.5194/bg-11-7125-2014 
Subramanian, A. N., Tanabe, S., Tatsukawa, R., Saito, S., and Miyazaki, N. (1987). Reduction in the testosterone levels by PCBs and DDE in Dall's porpoises of northwestern North Pacific. Mar. Pollut. Bull. 18, 643-646. doi: 10.1016/00 25-326X(87)90397-3

Tartu, S., Bustamante, P., Goutte, A., Cherel, Y., Weimerskirch, H., Bustnes, J. O., et al. (2014). Age-related mercury contamination and relationship with luteinizing hormone in a long-lived antarctic bird. PLoS One 9:e103642. doi: 10.1371/journal.pone.0103642

Tartu, S., Goutte, A., Bustamante, P., Angelier, F., Moe, B., Clément-Chastel, C., et al. (2013). To breed or not to breed: endocrine response to mercury contamination by an Arctic seabird. Biol. Lett. 9:20130317. doi: 10.1098/rsbl. 2013.0317

Taylor, B. L., Martinez, M., Gerrodette, T., Barlow, J., and Hrovat, Y. N. (2007). Lessons from monitoring trends in abundance of marine mammals. Mar. Mamm. Sci. 23, 157-175. doi: 10.1111/j.1748-7692.2006. 00092.x

Taylor, B. L., Wade, P. R., de Master, D. P., and Barlow, J. (2000). Incorporating uncertainty into management models for marine mammals. Conserv. Biol. 14, 1243-1252. doi: 10.1046/j.1523-1739.2000.99409.x

Theodorou, J., and Atkinson, S. (1998). Monitoring total androgen concentrations in saliva from captive Hawaiian monk seals (Monachus schauinslandi). Mar. Mamm. Sci. 14, 304-310. doi: 10.1111/j.1748-7692.1998. tb00718.x

Thomson, C. A., and Geraci, J. R. (1986). Cortisol, aldosterone, and leucocytes in the stress response of bottlenose dolphins, Tursiops truncatus. Can. J. Fish. Aquat. Sci. 43, 1010-1016. doi: 10.1139/f86-125

Trego, M. L., Hoh, E., Kellar, N. M., Meszaros, S., Robbins, M. N., Dodder, N. G., et al. (2018). Comprehensive screening links halogenated organic compounds with testosterone levels in male Delphinus delphis from the Southern California bight. Environ. Sci. Technol. 52, 3101-3109. doi: 10.1021/acs.est.7b04652

Trueman, C. N., MacKenzie, K. M., and Palmer, M. R. (2012). Identifying migrations in marine fishes through stable-isotope analysis. J. Fish Biol. 81, 826-847. doi: 10.1111/j.1095-8649.2012.03361.x

Trumble, S. J., Robinson, E. M., Berman-Kowalewski, M., Potter, C. W., and Usenko, S. (2013). Blue whale earplug reveals lifetime contaminant exposure and hormone profiles. Proc. Natl. Acad. Sci. U.S.A. 110, 16922-16926. doi: $10.1073 /$ pnas. 1311418110

Turner Tomaszewicz, C. N., Seminoff, J. A., Peckham, S. H., Avens, L., and Kurle, C. M. (2017). Intrapopulation variability in the timing of ontogenetic habitat shifts in sea turtles revealed using $\delta 15 \mathrm{~N}$ values from bone growth rings. J. Anim. Ecol. 86, 694-704. doi: 10.1111/1365-2656.12618

Vander Zanden, H. B., Bjorndal, K. A., Reich, K. J., and Bolten, A. B. (2010). Individual specialists in a generalist population: results from a longterm stable isotope series. Biol. Lett. 6, 711-714. doi: 10.1098/rsbl.2010. 0124
Vander Zanden, M. J., Clayton, M. K., Moody, E. K., Solomon, C. T., and Weidel, B. C. (2015). Stable isotope turnover and half-life in animal tissues: a literature synthesis. PLoS One 10:e0116182. doi: 10.1371/journal.pone.0116182

Vu, E. T., Clark, C. T., Catelani, K. N., Kellar, N. M., and Calambokidis, J. (2015). Seasonal blubber testosterone concentrations of male humpback whales (Megaptera novaeangliae). Mar. Mamm. Sci. 31, 1258-1264. doi: 10.1111/mms. 12191

Warne, R. W., Proudfoot, G. A., and Crespi, E. J. (2015). Biomarkers of animal health: integrating nutritional ecology, endocrine ecophysiology, ecoimmunology, and geospatial ecology. Ecol. Evol. 5, 557-566. doi: 10.1002/ ece 3.1360

Wasser, S. K., Lundin, J. I., Ayres, K. L., Seely, E., Giles, D., Balcomb, K., et al. (2017). Population growth is limited by nutritional impacts on pregnancy success in endangered Southern resident killer whales (Orcinus orca). PLoS One 12:e0179824. doi: 10.1371/journal.pone.0179824

Williard, A., Parga, M., Sagarminaga, R., and Swimmer, Y. (2015). Physiological ramifications for loggerhead turtles captured in pelagic longlines. Biol. Lett. 11:20150607. doi: 10.1098/rsbl.2015.0607

Witteveen, B. H., Worthy, G. A. J., and Roth, J. D. (2009a). Tracing migratory movements of breeding North Pacific humpback whales using stable isotope analysis. Mar. Ecol. Prog. Ser. 393, 173-183. doi: 10.3354/meps08231

Witteveen, B. H., Worthy, G. A. J., Wynne, K. M., and Roth, J. D. (2009b). Population structure of North Pacific humpback whales on their feeding grounds revealed by stable carbon and nitrogen isotope ratios. Mar. Ecol. Prog. Ser. 379, 299-310. doi: 10.3354/meps07900

Wolf, S. G., Snyder, M. A., Sydeman, W. J., Doak, D. F., and Croll, D. A. (2010). Predicting population consequences of ocean climate change for an ecosystem sentinel, the seabird Cassin's auklet. Glob. Chang. Biol. 16, 1923-1935. doi: 10.1111/j.1365-2486.2010.02194.x

Zupcic-Moore, J. R., Ruiz-Cooley, R. I., Paliza, O., Koch, P. L., and McCarthy, M. D. (2017). Using stable isotopes to investigate foraging variation and habitat use of sperm whales from northern Peru. Mar. Ecol. Prog. Ser. 579, 201-212. doi: $10.3354 /$ meps 12281

Conflict of Interest Statement: The authors declare that the research was conducted in the absence of any commercial or financial relationships that could be construed as a potential conflict of interest.

Copyright (c) 2018 Fleming, Kellar, Allen and Kurle. This is an open-access article distributed under the terms of the Creative Commons Attribution License (CC BY). The use, distribution or reproduction in other forums is permitted, provided the original author(s) and the copyright owner(s) are credited and that the original publication in this journal is cited, in accordance with accepted academic practice. No use, distribution or reproduction is permitted which does not comply with these terms. 